\title{
Metallic elements and oxides and their relevance to Laurentian Great Lakes geochemistry
}

\author{
Meagan N Aliff ${ }^{\text {Corresp., } 1}$, Euan D Reavie ${ }^{1}$, Sara P Post ${ }^{1}$, Lawrence M Zanko $^{1}$ \\ ${ }^{1}$ Natural Resources Research Institute, University of Minnesota - Duluth, Duluth, Minnesota, United States \\ Corresponding Author: Meagan N Aliff \\ Email address: aliff002@d.umn.edu
}

The Laurentian Great Lakes are the most studied system in lake geochemistry and have well-preserved chronological profiles. Metals play numerous critical roles in natural and anthropogenic characteristics of lake ecosystems, so patterns in the historical records of metals from sedimentary cores provide important information about environmental baselines and human impacts. Relevant studies of Great Lakes geochemistry are listed, and we follow with encyclopedic descriptions of metals and their oxides in the lakes. These descriptions include likely natural and anthropogenic sources of elements, their known history from previous paleoecological studies, and their status as potential contaminants of concern. Despite the well-studied geology of the Great Lakes catchment, sourcing elements was sometimes difficult due to materials often being moved long distances by glaciation and the global prevalence of atmospheric pollutants. We summarized available information on metals and their roles as geochemical indicators in the Great Lakes. 


\section{Metallic elements and oxides and their relevance to 2 Laurentian Great Lakes geochemistry}

3 Meagan N. Aliff*, Euan D. Reavie, Sara P. Post, Lawrence M. Zanko

4 Natural Resources Research Institute, University of Minnesota Duluth, Duluth, Minnesota, 5 55811, United States

$6 \quad$ * Corresponding author:

7 Email address: aliff002@d.umn.edu 


\section{Abstract}

9 The Laurentian Great Lakes are the most studied system in lake geochemistry and have wellpreserved chronological profiles. Metals play numerous critical roles in natural and anthropogenic characteristics of lake ecosystems, so patterns in the historical records of metals from sedimentary cores provide important information about environmental baselines and human impacts. Relevant studies of Great Lakes geochemistry are listed, and we follow with encyclopedic descriptions of metals and their oxides in the lakes. These descriptions include likely natural and anthropogenic sources of elements, their known history from previous paleoecological studies, and their status as potential contaminants of concern. Despite the wellstudied geology of the Great Lakes catchment, sourcing elements was sometimes difficult due to materials often being moved long distances by glaciation and the global prevalence of atmospheric pollutants. We summarized available information on metals and their roles as geochemical indicators in the Great Lakes.

\section{Introduction}

An understanding of past conditions is essential for potential remediation efforts in an aquatic system because it can be used to estimate natural baseline, remediation targets, timing and causes of impacts, and positive effects of existing remedial efforts. During the Anthropocene epoch, human impacts have far exceeded natural changes in the landscape through agriculture and industry, mobilizing sediments and releasing pollutants into the air and water. These activities leave geochemical markers in sedimentary records of aquatic systems. Sediment cores can be collected and dated to reveal local geochemical histories. Metals are of particular interest because they record a history of pollution going back thousands of years (Heim \& Schwarzbauer, 2012). In order to determine the historical extent of contamination caused by human activity, concentrations of potential pollutants must be compared to the baseline occurrences from natural sources (Alderton, 1985). Geochemistry depends on location-specific soil and bedrock composition, so it is important to consider natural sources of inorganic materials relative to anthropogenic sources. As Tourtelot (1971) describes, "[ $t$ ]he types of rocks that form geologic units in the Earth's crust supply most of the raw materials from which soils are formed and from which water derives its inorganic constituents."

Sediments in lake systems are especially useful in geochemical studies because lakes act as sinks for inorganic materials. The best environments for geochemical studies are aquatic environments that have stable sedimentary basins allowing steady deposition of fine-grained material suitable for fixation of pollutants. Ideally, sediments are reducing (anoxic) at the sediment/water interface and thereby support minimal post-depositional mobility. According to Heim \& Schwarzbauer (2012), the Laurentian Great Lakes are the most studied system in lake geochemistry and they have well-preserved chronological profiles (Reavie et al., 2017). These studies reveal a history of contamination starting with European settlement around 1850 and increasing over the next century with increases in industry, forest fires, and the burning of fossil fuels, which supported increased flux of land-based and atmospheric pollutants to the lakes. More recently, 
48 Great Lakes Water Quality Agreement (Canada \& United States of America, 1972) have

49 mitigated inputs of these pollutants and have also led to their remediation to some degree. A

50 detailed list of pertinent studies along with associated analytes is provided in Table 1.

\section{Survey methodology}

This review summarizes what is known of inorganic paleogeochemistry in the Laurentian Great

53

54

55

56

57

58

59

60 Lakes, itemized by metallic elements. To date, the Great Lakes system has been considered in parts (Table 1), so we aimed to synthesize all relevant literature to create a central understanding of metallic geochemistry in the lakes. This review is the first of a pair of manuscripts exploring this topic, the second being a retrospective geochemical analysis of 11 sediment cores collected from the lakes (Aliff et al., 2020). Here we provide an overview of the metallic elements and oxides with a focus on their relevance in the Laurentian Great Lakes. Major aims were to define the analytes in terms of their sources and characterize their potential importance as anthropogenic stressors.

\section{Geology and Geomorphology of the Great Lakes Basin}

The geology of the Great Lakes basin has been extensively studied. Broadly, the basin is bounded to the north by the upland Precambrian-age Canadian Shield, which is dominated by intrusive rocks (Fig. 1).

The basin is bound to the south by a lowland region of Paleozoic sedimentary rocks such as limestones, dolomites, and sandstones (Fig. 1; Larson \& Schaetzl, 2001). The basins of lakes Erie and Michigan, as well as most of the Lake Ontario basin, are in this lowland region. The Lake Superior basin is almost entirely in the Canadian Shield, and Lake Huron straddles the two.

The Canadian Shield is the exposed portion of the North American craton, which forms the core of the continent. "The Canadian Shield region north of Lake Superior features a series of Greenstone belts in Archean rocks up to 2.5 billion years. ... Near the bottom of typical greenstone strata are ultrabasic volcanic and intrusive [rocks], which can yield chromite and nickel ores. Overlying these beds are mafic and felsic [volcanic rocks], often with ores of gold, silver, copper, and zinc. At the top of the sequence are sedimentary rocks which yield manganese, barite, and iron ores" (Kerfoot \& Nriagu, 1999). These greenstone belts are up to hundreds of kilometers long and wide.

The Midcontinent Rift System in the western Lake Superior basin is a package of basalt flows and sedimentary rocks up to $25 \mathrm{~km}$ thick (Keays \& Lightfoot, 2015). Between approximately 1.109 and 1.084 billion years ago (Early to Middle Proterozoic, Fig. 1), there was a prolonged period of extension in the middle of what is now North America, which produced large quantities of basaltic magmas and a large number of sills, dikes, mafic intrusive complexes, and intrusions of alkali and carbonatitic composition (Keays \& Lightfoot, 2015; Kerfoot \& Nriagu, 1999). Most of the exposed rift outcrop is found around Lake Superior, but evidence suggests that it also underlies the Michigan Basin feature of Lower Michigan (Fig. 1).The rift structure extends to the southwest as far as Kansas. Many of the major metallic mineral prospects and ore bodies in the 
86 Great Lakes region are part or product of the Midcontinent Rift (Ojakangas, Morey \& Green, 87 2001).

88 The Lake Huron basin is largely within the Paleozoic sedimentary rock region, though the

89

90

91

92

93

94

95

96

97

98

99

100

101

102

103

104

105

106

107

108

109

110

111

112

113

114

115

116

117

118

119

120

121

122

123

124

125 northern shore is on the edge of the Canadian Shield (Hough, 1958). Lakes Michigan, Ontario, and Erie are almost all entirely within the Paleozoic province, which is dominated by the sedimentary rocks of the Michigan Basin (Fig. 1). Surrounding the Michigan Basin is an erosionresistant sequence of Silurian dolomite. On top of this dolomite sandstone, shale, limestone, and evaporite sediments were deposited (LaBerge, 1994). Lake Erie is largely underlain and surrounded by Devonian limestones and shales, and Lake Ontario is underlain by Ordovician limestones and shales. The Silurian rocks outcrop between the two lakes, forming the Niagara Escarpment, which is the foundation of Niagara Falls (Sly \& Thomas, 1974; Fig. 1).

The overlying sediment in the Great Lakes basin is strongly influenced by glaciation. The lowland region which includes the Erie and Michigan basins along with most of Huron and Ontario is blanketed by glacial sediments often between 50 and $350 \mathrm{~m}$ in thickness. The upland region of Superior, Georgian Bay, and Ontario basins has thin discontinuous layers of glacial sediments (Larson \& Schaetzl, 2001). For a more detailed description of glacial processes in the Great Lakes, see Larson \& Schaetzl (2001) and Sly \& Thomas (1974). Because sediments may be derived from glacial till transported long distances, sourcing of materials is difficult without more in-depth mineralogical analyses. Hence, excepting documented and localized metallic ores, confirming ultimate sources for materials found in lake sediment cores can be challenging.

\section{Metals in the Great Lakes}

A discussion of the influence that rock type can have on elemental concentrations can provide some geological context for the presence of certain metallic analytes in lake sediments. For example, arsenic (As) generally occurs in lower concentrations in igneous rocks compared to sedimentary rocks, as shown in Table 2 which is a combined version of two tables from National Research Council (1977). The range of metal ppm values can be quite broad, even within a specific rock type. For instance, the Biwabik Iron Formation in Minnesota is a sedimentary iron ore deposit, and the range of its As content as reported by Morey (1992) was $<3$ to $40 \mathrm{ppm}$ which is small relative to the 1 to $2,900 \mathrm{ppm}$ range shown in the table. Other metals show different ranges of composition based on rock type, but it is beyond the scope of this report to provide those details for all metals.

These bedrock characteristics can provide some information on sources of metals in the environment, but what best explains an element's presence in Great Lakes sediment cores, especially during the Anthropocene epoch? While bedrock geology is important to consider, unconsolidated surficial materials are the more significant contributors to sediment loading. As reported to the U.S. Army Corps of Engineers by the Great Lakes Commission (2008), more than 65 million tons of soil may be eroding annually in the Great Lakes basin based on modeling data by Ouyang \& Bartholic (2003), with agricultural land being the largest known contributor to soil erosion in the basin (65 to 77\%). Therefore, soils are probably the most relevant source of catchment inputs, but with the understanding that soils are also derived from bedrock sources 
126 that may not be proximal to eroding soils, they may not reflect local bedrock geology. A large

127 portion of lake contamination is also sourced atmospherically, such as by fossil fuel consumption

128 and metal smelting (refining), making the identification of a specific contributor even more

129 difficult. What this review shows is that human activity and society's reliance on and demand for

130 natural resources is ultimately the driver for nearly every metal or metal-containing compound

131 whose extraction, production, and use contribute to their presence in the environment above

132 background levels.

133 What follows is an encyclopedic list of metals in Great Lakes sediments. All available research, 134 and best judgement, was used to characterize metals as they pertain to Great Lakes geochemistry.

135 This included as necessary for each analyte: source, known history, and contaminant properties.

136 Alkali Metals

137 Lithium

138 Contaminant status in the Great Lakes: Unknown but possible

139 Dominant sources: Weathering of rocks

140 Background and relevance to the Great Lakes: Lithium (Li) is the $27^{\text {th }}$ most abundant element

141 in the Earth's crust and has been found to have a concentration of $0.07-40 \mu \mathrm{g} / \mathrm{L}$ in fresh waters

142 (Shahzad et al., 2016). Li is found in small amounts in nearly all rocks, averaging $40 \mathrm{ppm}$ in soil

143 (Emsley, 2002). At low concentrations, it seems to stimulate plant growth (Aral \& Vecchio-

144 Sadus, 2008). Lithium's biological impacts are not well understood, although it is commonly

145 used as a psychoactive drug. $\mathrm{Li}$ is an issue of emerging concern in surface waters due to its

146 increasing use in drugs, batteries, and alloys (Tkatcheva et al., 2015). However, its prevalence is

147 not well known because environmental releases of Li are not regulated in North America. It can

148 be used in paleolimnology to account for increasing sediment inputs into a system in order to

149 determine what amount of trace metal inputs are from anthropogenic sources in addition to

150 natural sediment inputs (Ikem and Adisa, 2011). Historically, increases in Li in the sediment

151 record of Northeast Germany indicated erosion of the catchment area (Selig, Leipe \& Dörfler,

152 2007). Rossmann \& Barres (1988) found median Li concentrations (dissolved and particulate)

153 ranged from $0.64 \mathrm{ppb}$ in Lake Superior waters to $2.4 \mathrm{ppb}$ in Lake Ontario in samples collected

154 between 1981 and 1983. They found that Lakes Erie, Michigan, and Ontario had significantly (p

$155>0.05$ ) higher concentrations of Li than Lake Superior waters. In Lake Superior, Nussmann

156 (1965) found Li concentration did not vary systematically in sediment cores. Concentrations in

157 surface sediments averaged $45 \mathrm{ppm}$, while the average concentration in glacial sediments was 96

$158 \mathrm{ppm}$. Nussmann (1965) theorized that the fact Li was not sorbed in clays may mean there is little

159 sediment-water exchange of Li in Lake Superior.

160 Sodium

161 Contaminant status in the Great Lakes: Associated with urban environments, mining and

162 other industries

163 Dominant sources: The Michigan basin (Fig. 1) due to evaporation of sea water, road salt

164 applications, domestic and industrial wastewater

165 Background and relevance to the Great Lakes: Sodium $(\mathrm{Na})$ is the $6^{\text {th }}$ most abundant element, 166 making up 2.36\% of the Earth's crust (Lindsay, 1968; Taylor, 1964). Na is an essential element 
167 to life as the principal cation of extracellular fluids in higher animals. It is readily weathered and

168 highly soluble in aqueous environments, where it has a long residence time (Mittlefehldt, 1999b).

$169 \mathrm{Na}$ enters the hydrosphere from urban environments through road salt and waste water treatment

170 plants (Chambers et al., 2016). Due to its long residence time, Na has been persistently higher

171 than background levels in Lakes Superior, Michigan, and Huron over the last 150 years, though

172 it did peak in Lakes Erie and Ontario between 1965 and 1975, decreasing in more recent years

173 due to a reduction in point source discharges (Chapra, Dove \& Warren, 2012). Kemp and

174 Thomas (1976b) and Kemp et al. (1978) considered Na a conservative element in their cores

175 from Lakes Ontario, Erie, Huron, and Superior over the period from pre-settlement to the early

176 1970s and observed relatively stable concentrations over the interval. Shaw Chraïbi et al. (2014)

177 found increases in Na starting in 1952 with a gradual decline between 1952 and 1990 in their

178 core from eastern Lake Superior. In their core of western Lake Superior, they found stable

179 concentrations of Na up to 1955 ending with an increase in concentration likely resulting from

180 urban inputs in the vicinity of Duluth, Minnesota. Reavie et al. (2005) found that $\mathrm{Na}$

181 concentrations gradually increased in the 1800s with European settlement in their core from

182 Lake George, just downgradient from Lake Superior. Sgro and Reavie (2017) attributed Na in

183 their cores in Lake Erie to road salt impacts and found the highest concentrations in surface

184 sediments. In Lake Huron, Sgro and Reavie (2018) associated Na with edaphic deposits and

185 found concentrations remained stable until around 2011.

\section{Potassium}

187 Contaminant status in the Great Lakes: Yes, related to industrial and agricultural activity

188 Dominant sources: Weathering

189 Background and relevance to the Great Lakes: Potassium $(K)$ is the $7^{\text {th }}$ most abundant

190 element, making up 2.09\% of the Earth's crust (Schoeld, 1968; Taylor, 1964). It is found in all

191 soils and exists in several forms, some readily weathered and dissolved. $\mathrm{K}$ is an essential nutrient

192 in both plant and animal cells, being more important in plants as $\mathrm{Na}$ is more important in

193 animals. K leaches into rivers from fertilizer applications and is released with burning biomass

194 (Schoeld, 1968; Pompeani et al., 2013). Kemp and Thomas (1976b) and Kemp et al. (1978)

195 considered K a conservative element in their cores from Lakes Ontario, Erie, Huron, and

196 Superior over the period from pre-settlement to the early 1970s and observed relatively stable

197 concentrations over the interval except near the sediment-water interface, where they observed

198 increases and decreases in concentration related to fluctuating levels of organic matter. Shaw

199 Chraïbi et al. (2014) found increases in K in 1952 associated with mining activity with a gradual

200 decline between 1952 and 1990 in their core of eastern Lake Superior. In their core of western

201 Lake Superior they found stable concentrations of $\mathrm{K}$ up to 1955, ending with an increase in

202 concentration. Pompeani et al. (2015) observed increases in K concentration in their core near

203 Isle Royale, Lake Superior around $5800 \mathrm{BP}$ that matched the dating of $\mathrm{Cu}$ artifacts found in the

204 region, suggesting that concentrations were related to ancient mining practices. K concentrations

205 do not increase with modern mining techniques, implying inputs from wood fires or perhaps

206 some other difference between modern and ancient mining (Pompeani et al., 2015).

207 
Rubidium

209 Contaminant status in the Great Lakes: None known

210 Dominant sources: Lithogenic, silicates, coal burning

211 Background and relevance to the Great Lakes: Rubidium $(\mathrm{Rb})$ is a widely distributed element

212 that forms no minerals. It is concentrated in silicates and is soluble in aqueous solutions

213 (Simmons, 1999). It has a concentration of about 90 ppm in the Earth's crust (Mosheim, 1968b;

214 Taylor, 1964). $\mathrm{Rb}$ is considered a conservative lithogenic element and can be used to control for

215 natural inputs when measuring the extent of anthropogenic inputs of other elements. $\mathrm{Rb}$ is also

216 thought to be immobile in the sediments (Boës et al., 2011). It is considered an ultra-trace

217 element for humans and other organisms, and it undergoes consistent biomagnification in the

218 food web (Campbell et al., 2005). Most Rb in lakes is related to geologic features and minerals in

219 soils. A possible anthropogenic source is coal burning, especially from the Nanticoke Generating

220 Station on Lake Erie, which was the largest coal-fired power station in North America until it

221 was decommissioned in 2013 (Campbell et al., 2005).

222 Cesium

223 Contaminant status in the Great Lakes: Yes, in the form of ${ }^{137} \mathrm{Cs}$

224 Dominant sources: Erosion and weathering. Radioactive isotope ${ }^{137} \mathrm{Cs}$ from atmospheric

225 deposition after nuclear weapons testing

226 Background and relevance to the Great Lakes: Cesium (Cs) is widely distributed in the

227 Earth's crust at low concentrations (Mosheim, 1968a). It averages $1 \mathrm{ppm}$ in granite and $4 \mathrm{ppm}$ in

228 sedimentary rocks. In fresh water, Cs occurs naturally from erosion and weathering and at

229 between 0.01 and $1.2 \mu \mathrm{g} / \mathrm{L}$. Cs has serious health impacts in the form of its radioactive isotopes,

230 which cause tissue damage and disruption of cellular function. Cs is used in paleolimnological

231 studies because the isotope ${ }^{137} \mathrm{Cs}$ is a radionuclide marker for the early 1960s (Gobeil, Tessier \&

232 Couture, 2013). The majority of ${ }^{137} \mathrm{Cs}$ in surface waters in North America, including the Great

233 Lakes, is due to nuclear weapons testing, which began in 1952 and ended in 1963 with the

234 Limited Test Ban Treaty. In the Great Lakes, the maximum deposition of ${ }^{137} \mathrm{Cs}$ was in the spring

235 of 1963, though peaks in the sediment may be as much as two years later (ASTDR, 2004a;

236 Reavie et al., 2005). The radionuclide is strongly bound to expandable lattice clay minerals such

237 as illite in the Great Lakes, so it tends to be a reliable temporal indicator in sediment profiles.

238 Alkaline Earth Metals

239 Magnesium

240 Contaminant status in the Great Lakes: Some historical contamination associated with

241 taconite tailings in the western part of Lake Superior

242 Dominant sources: Limestone in Lake Michigan basin (Fig. 1); dolomite content of bluffs along

243

244

245 north shore of Lake Erie (Chapra, Dove \& Warren, 2012)

Background and relevance to the Great Lakes: Magnesium $(\mathrm{Mg})$ is abundant in nature, always as part of a compound. It is the $8^{\text {th }}$ most abundant crustal element and $6^{\text {th }}$ most abundant

246

247

248 metallic element, making up 2.5\% of the Earth's crust (Gross, 1968). Mg readily dissolves during weathering of rocks and enters the hydrosphere (Mittlefehldt, 1999a). It is a necessary element for life and one of the four bulk metals in the human body (Schroeder, Nason \& Tipton, 
273

274

275

276

277

278

279

280

281

282

283

284

285

286

287

288

289

1969). In lake sediment records, increases in $\mathrm{Mg}$ are frequently associated with erosion (Mackereth 1966; Norton, Binford \& Kahl, 1992), and in more modern times, Mg is associated with road dust (Spengler et al., 2011). Kemp and Thomas (1976b) and Kemp, Thomas \& Gregory (1978) found Mg as one of the major elements in the sediment of Lakes Ontario, Erie, Huron, and Superior and found it to be generally uniform in all of their cores. In a sediment core from western Lake Superior, Shaw Chraïbi et al. (2014) found peaks in Mg around 1972, which they associated with taconite processing and waste discharge near Silver Bay, MN. Arthur et al. (1973) found $\mathrm{Mg}$ to be a component of the dissolved solids from the tailings. But considering the core locations of Shaw Chraïbi et al. (2014) and the circulation patterns of Lake Superior, the association in their cores is unclear. Pompeani et al. (2015) found Mg concentrations in Lake Superior near McCargoe Cove to be relatively stable over their 8,400 year record, though increases are believed to reflect changes in the delivery of metals to the basin, as high concentrations of $\mathrm{Mg}$ are found in the bedrock surrounding $\mathrm{Cu}$ lodes.

\section{Calcium}

Contaminant status in the Great Lakes: Yes, related to runoff and mining

Dominant sources: Carbonate minerals such as those found in the Midcontinent Rift and in the Paleozoic (carbonate-rich) bedrock surrounding the lower Great Lakes (Fig. 1); detrital material Background and relevance to the Great Lakes: Calcium $(\mathrm{Ca})$ is the $5^{\text {th }}$ most abundant element in the Earth's crust. It is one of the most widely distributed elements, present in almost all natural waters. $\mathrm{Ca}$ is the most common inorganic element in higher animals and necessary for most life, concentrating in skeletons, exoskeletons, and shells and distributed throughout tissues. It is also needed for plant meiosis and the maintenance of soil $\mathrm{pH}$ (Mantell, 1968). In urban environments, Ca pollution comes from building materials (Chambers et al., 2016). The Great Lakes are rich in limestone (especially in the Paleozoic province surrounding the lower Great Lakes (Fig. 1)) and therefore calcium carbonate $\left(\mathrm{CaCO}_{3}\right)$. In the summer, the lakes can experience periods of "whiting," when warming waters release $\mathrm{CaCO}_{3}$ into the water column and dissolved $\mathrm{CO}_{2}$ is removed by algae. Sediment cores in the Great Lakes have fluctuating $\mathrm{CaCO}_{3}$ levels with times of warmer climate (Meyers, 2003). Due to its long residence time, Ca has been persistently increasing in Lakes Superior, Michigan, and Huron over the last 150 years, though it did peak in Lakes Erie and Ontario between 1965 and 1975, decreasing in more recent years due partly to the introduction of quagga mussels (Chapra, Dove \& Warren, 2012), who use the Ca in formation of shells. In Lakes Superior and Huron, Kemp et al. (1978) considered Ca a conservative element, representing terrigenous sources of materials in their sediment cores. In Lakes Ontario and Huron, Kemp and Thomas (1976b) grouped Ca with the carbonates, finding decreasing concentration in parts of Lake Erie and increases to very high surface concentrations in Lake Ontario above the Ambrosia pollen horizon (marking European settlement and deforestation), which they attributed to the dissolution of detritus. Shaw Chraïbi et al. (2014) found increases in $\mathrm{Ca}$ in 1952 that they associated with overall mining activity in the basin, with a gradual decline between 1952 and 1990 in their core of eastern Lake Superior. In their core of western Lake Superior, they found stable concentrations of Ca until 1955 followed by an increase in concentration. 
290

291

292

293

294

295

296

297

298

299

300

301

302

303

304

305

306

307

308

309

310

311

312

313

314

315

316

317

318

319

320

321

322

323

324

325

326

327

328

329

330

331

332

Strontium

Contaminant status in the Great Lakes: Yes, related to mining, fossil fuels, and industry Dominant sources: Ca-containing rocks and minerals, dust, mining waste, fossil fuels, other industries

Background and relevance to the Great Lakes: Strontium $(\mathrm{Sr})$ is the $15^{\text {th }}$ most common element on Earth, making up $0.034 \%$ of the Earth's crust (Höllriegl \& München, 2011). Mean dissolved $\mathrm{Sr}$ in the Great Lakes ranged from $42 \mathrm{ppb}$ in Lake Superior to $180 \mathrm{ppb}$ in Lake Ontario between 1981 and 1985 (Rossmann \& Barres, 1988). There is a small amount of Sr in many rocks and minerals, but it is present in all Ca-bearing rocks, minerals, and soils. Sr is naturally released from the Earth's crust as dust and wind. Human processes that contribute to Sr release include mining, milling and processing, pyrotechnics, and phosphate fertilizers. Other sources for Sr pollution include association with chloride in road salt in the Lake Ontario watershed (Meriano, Eyles \& Howard, 2009) and iron corrosion products from residential drinking water distribution systems (Gerke et al., 2013). It is also present in coal and becomes concentrated in coal fly ash (Sherman et al., 2015). Spengler et al. (2011) also attributed increases in Sr with road dust, brake dust, and diesel tail pipe emissions near Buffalo Peace Bridge on the Niagara River between Lakes Erie and Ontario. Sr is chemically similar to $\mathrm{Ca}$ and can deposit in bones. In fish, otoliths and other biogenic carbonates $\mathrm{Sr}$ and $\mathrm{Sr} / \mathrm{Ca}$ ratios can be used to reconstruct past water temperatures and salinity because the partitioning constant for those elements varies with those parameters (Limburg et al., 2015; Carilli et al., 2015). Sr found at natural concentrations has low toxicity, but radioactive $\mathrm{Sr}$ can be dangerous, especially because it deposits in bones, leading to bone cancer (Hampel, 1968e). Sr has several radioactive isotopes, the longest lived being ${ }^{90} \mathrm{Sr}$ with a half-life of 29 years. Radioactive $\mathrm{Sr}$ was released into the atmosphere between 1945 and 1980 via nuclear weapons testing. While present in Great Lakes water, a 1984 study indicated that radioactive Sr was within safe drinking water parameters (Durham \& Joshi, 1984), and it is likely that radioactivity has since decreased. Shaw Chraïbi et al. (2014) found increases of $\mathrm{Sr}$ from pre-settlement 1952 in their eastern core of Lake Superior associated with mining. In their western core, they found a peak of Sr between 1955 and 1967, which they associated with taconite processing in Silver Bay.

Barium

Contaminant status in the Great Lakes: Yes, listed as a sediment and water contaminant of the Saginaw Bay and the Rouge River Great Lakes Areas of Concern (AOCs) (Hartig and Thomas, 1988)

Dominant sources: Barite, drilling fluid (oil and gas industry)

Background and relevance to the Great Lakes: Barium $(\mathrm{Ba})$ is the $14^{\text {th }}$ most abundant element in the Earth's crust (Hampel 1968a; Smith, 1999). Ba is highly reactive and is precipitated with sulfate and carbonates. Therefore, it is not very mobile in soils and remains bound to particles in circumneutral pH (Madejón, 2013). When soluble, Ba is moderately acutely toxic (Moore, 1991). Barite (barium sulfate) is used as a drilling fluid/mud for oil and gas wells. Ba was historically used as a tracer in place of lead for vehicle emissions via diesel and unleaded gasoline (for example, in sediment cores from an urban Hawaii stream described by Sutherland (2000)), but newer diesel fuels are low-sulfur and do not need to use Ba as a sulfur-scavenging agent (ASTDR, 2007b). Ba was found in at least 798 of 1,684 current or former EPA National

Peer] reviewing PDF | (2020:01:44690:1:0:NEW 22 Mar 2020) 
333 Priorities List (NPL) hazardous sites in the United States. In Lake St. Clair, sediment Ba was at 334 non-detect levels in 1983 and up to $48.37 \mathrm{mg} / \mathrm{kg}$ in 2010 (Alsaffar, 2017). According to USEPA 335 guidelines, $20-60 \mathrm{mg} / \mathrm{kg}$ is considered moderately polluted with $\mathrm{Ba}$, and $>60 \mathrm{mg} / \mathrm{kg}$ is heavily 336 polluted. In Saginaw Bay, Ba levels up to $422 \mathrm{mg} / \mathrm{kg}$ were found (Hartig and Thomas, 1988). In 337 contrast, Ba was one of the elements least enriched by anthropogenic sources in Lake Erie according to Yuan (2017). In Lake Superior, Shaw Chraïbi et al. (2014) saw, in an eastern core, an increase in Ba from post-settlement through $\sim 1952$ associated with mining, peaking around 1960. In a western core, they observed a Ba peak between 1955 and 1967 associated with taconite processing waste discharge near Silver Bay.

\section{$\underline{\text { Transition Metals }}$}

\section{Scandium}

345 Contaminant status in the Great Lakes: None known element in the Earth's crust (Horovitz, 1975). Sc is present in small amounts in hundreds of minerals, as there are no geological processes to concentrate it and it lacks affinity for common ore-forming ions (Emsley, 2014; USDOI \& USGS, 2017). Hence, no localized sources of Sc are known in the Great Lakes basin, and no Sc is mined in the United States. Sc is not known to be a nutrient for any organism and has, in fact, been found to be toxic in high concentrations due to its high affinity for proteins (Sánchez-González et al., 2013). According to Horovitz (1975), the average soil content of $\mathrm{Sc}$ is $7 \mathrm{ppm}$, with a range of 3-50 ppm. Sc is a useful reference element that can be compared to the concentration of other, less conservative elements in order to gain more useful information about that element's variability in time (Peirson, Cawse \& Cambray, 1974; Dias \& Prudêncio, 2008). Sc has not been greatly studied in the Great Lakes, although Winchester (1972) found the natural inputs of Sc to Lake Michigan to be $0.004 \mathrm{ppb}$ per year and the natural output to be $0.027 \mathrm{ppb}$ per year. Shimp et al. (1971) and Reavie et al. (2005) found that Sc concentrations did not vary over time in their sediment cores from southern Lake Michigan and Lake George, respectively.

Titanium

363 Contaminant status in the Great Lakes: Some atmospheric contamination from vehicle and coal emissions along with catchment erosion

Background and relevance to the Great Lakes: Comprising $0.63 \%$ of the Earth's crust by mass, Titanium (Ti) is the $9^{\text {th }}$ most abundant element and the $7^{\text {th }}$ most abundant metal. It is widely distributed in a diverse range of rocks, soils, minerals, and atmospheric dust (Barksdale, 1968). According to Woolrich (1973), Ti ranges in concentration in the air from 0.003-0.07 ppb. It is considered a weathering-resistant, immobile mineral, generally insoluble and not mobilized by acidification (Norton, Binford \& Kahl, 1992; Schaetzl, Mikesell \& Velbel, 2006). Increases in $\mathrm{Ti}$ are generally associated with erosion. Titanium dioxide $\left(\mathrm{TiO}^{2}\right)$ is useful as an indicator of erosion rates and for the normalization of other trace metals, but one must take care to account 
374 for atmospheric concentrations of Ti, which may lead to inconsistent results (Norton, Binford \& 375 Kahl, 1992). Spengler et al. (2011) performed a study of air toxics near the Buffalo Peace Bridge

376 U.S. Border crossing on the east end of Lake Erie and found two-fold increases in Ti downwind

377 of the city of Buffalo, which they attributed to coal combustion, traffic emissions, and road dust.

378 In rock, Ti is known to occur in gabbroid rocks in the Midcontinent Rift near the south shore of

379 Lake Superior (Fig. 1; Wisconsin Geological and Natural History Survey 2019), but it is

380 probably much more widespread. Ti is considered a conservative element and was found to be

381 generally constant in sediment cores from Lakes Ontario, Erie, Huron, and Superior (Kemp et

382 al., 1976; Kemp et al., 1978; Pompeani et al., 2015).

\section{Vanadium}

384 Contaminant status in the Great Lakes: Yes, especially in Lake Michigan due to past

385 contamination from the BP Whiting Refinery

386 Dominant sources: Weathering, fossil fuel emissions

387 Background and relevance to the Great Lakes: Vanadium (V) is the $22^{\text {nd }}$ most abundant

388 element in the Earth's crust at around 130 ppm by mass (Foote Mineral Co., 1968; Sigel, Sigel \&

389 Sigel, 2013). V is non-toxic at common concentrations, though it can bioaccumulate, and at

390 higher concentrations it can have negative effects on the respiratory system. It is an essential

391 trace element for many organisms, and deficiency is associated with a variety of conditions

392 including problems in growth, reproduction, and blood formation (Gummow, 2011;

393 Venkataraman \& Sudha, 2005). V is present in more than 50 minerals and its main natural source

394 in the environment is weathering of rocks, hence it is difficult to determine specific rock sources

395 in the Great Lakes. Anthropogenic inputs are largely atmospheric; $\mathrm{V}$ is a major component of

396 coal- powered and other fossil fuel emissions. V has been a contaminant of more recent concern

397 and has been found in 319 out of 1,699 hazardous sites on the EPA's National Priorities List

398 (ASTDR, 2012c). Shahin, Paode \& Holsen (2000) found an increase of V dry deposition in the

399 urban area of Chicago compared to other sampling sites around Lake Michigan due to emissions

400 from industrial sources. Kemp et al. (1978) found V to be stratigraphically uniform in most of

401 their cores of Lakes Huron and Superior taken in the early 1970s, though there were

402 anthropogenic inputs. One of the major sources of V pollution on the Great Lakes is the BP

403 Whiting Refinery on the southwestern shore of Lake Michigan. This refinery stored petroleum

404 coke (petcoke), a byproduct of the refining process, at a site in Chicago operated by KCBX

405 Terminals Company until 2016. The mounds of petcoke at this site were a source of windborne

$406 \mathrm{~V}$ and negatively impacted air quality in the area (ASTDR, 2016). BP also discharged 39 barrels

407 of oil into Lake Michigan in March 2014, and the EPA found that they failed to implement a

408 proper spill prevention plan (Bassler, 2016).

409 Chromium

410 Contaminant status in the Great Lakes: Yes, listed as a sediment contaminant or water

411 contaminant in 17 AOCs in the Great Lakes (Hartig and Thomas, 1988)

412 Dominant sources: Greenstone belts in Archean rocks in Canadian Shield north of Lake

413 Superior (Fig. 1), chromine, steel production, leather tanning

414 Background and relevance to the Great Lakes: Chromium $(\mathrm{Cr})$ is an essential human nutrient

415 at low concentrations but is toxic at higher levels, acting on the respiratory tract and as a 
416 carcinogen (Ilton, 1999; ASTDR, 2012b). Major anthropogenic sources of Cr in natural waters

417 include waste from electroplating, leather tanning, and textile industries. Cr is important in use of

418 the steel industry, as it is an essential component of stainless steel (USDOI \& USGS, 2017).

419 Yuan (2017) included $\mathrm{Cr}$ in group of elements most enriched by anthropogenic loading in Lake

420 Erie. Walters, Wolery \& Myser (1974) also observed significant enrichment in Lake Erie cores

421 since about 1950. Reavie et al. (2005) associated peaks of $\mathrm{Cr}$ in their cores of Lake George with

422 the now defunct Northwestern Leather Company which discharged directly into St. Mary's

423 River, just downstream from Lake Superior. $\mathrm{Cr}$ in their cores peaked around 1946 and sharply

424 dropped in the late 1950s after the tannery closed. Kemp et al. (1978) found only small amounts

425 of localized enrichment in their cores of Lakes Superior and Huron.

426 Manganese

427 Contaminant status in the Great Lakes: Yes, listed as a sediment contaminant or water

428 contaminant in of the following AOCs: Clinton River, Cuyahoga River, Oswego River (Hartig

429 and Thomas, 1988)

430 Dominant sources: Terrigenous sources including sedimentary rocks overlying the Canadian

431 Shield above Lake Superior (Fig. 1), contaminant from iron and steel production;

432 ferromanganese nodules

433 Background and relevance to the Great Lakes: Manganese (Mn) is the $12^{\text {th }}$ most abundant

434 element in the Earth's crust and biosphere and is considered one of the five essential trace

435 elements to nearly all organisms (Hampel, 1968d; Nádaská et al., 2012; Uren, 2013). In high

436 chronic doses Mn impacts the human central nervous system (Nádaská, Lesny \& Michalik,

437 2012). Mn is common in the Great Lakes, especially in Lakes Michigan and Ontario where it

438 occurs in nodular concretions and coatings on sand particles and rocks (Sly and Thomas, 1974).

439 Mn preferentially sorbs to heavy metals and nodules can act a sink for those metals; it is

440 especially associated with Co and Fe (Kemp et al., 1978; Uren, 2013), and it diffuses and

441 precipitates with other redox sensitive elements such as Fe and As (Sly and Thomas, 1974;

442 Azcue, Rosa \& Mudroch, 1996); hence, Mn is a common co-contaminant from mining activities.

443 Ferromanganese concretions found in Lake Superior are thought to be linked to activity of iron

444 oxidizing bacteria (Dittrich et al., 2015). Mn occurs in sediment cores but often concentrates near

445 the sediment water interface because it is extremely redox sensitive. It tends to migrate through

446 anoxic porewater and then becomes trapped by oxic surface sediments, thereby making it

447 difficult to establish its actual depositional history (Kemp and Thomas, 1976a; Kemp and

448 Thomas, 1976b; Sly and Thomas, 1974; Kemp et al., 1978; Azcue, Rosa \& Mudroch, 1996;

449 Reavie et al., 2005; Shaw Chraïbi et al., 2014; Kuzyk, Macdonald \& Johannessen, 2015). In

450 Lake Erie and shallow areas of Lake Ontario, which are seasonally anoxic, Mn is able to escape

451 from the sediment and does not accumulate at the surface as it does in other lakes (Kemp and

452 Thomas, 1976b). Peaks in Mn in lower layers of sediment cores are often related to

453 anthropogenic activities such as taconite processing or as a contaminant from iron and steel

454 production (Kemp et al., 1978; Reavie et al., 2005; Chambers et al., 2016), hence the record of

$455 \mathrm{Mn}$ is particularly relevant to Lake Superior.

456 Iron

457 Contaminant status in the Great Lakes: Yes, listed as a sediment contaminant or water 
458

459

460

461

462

463

464

465

466

467

468

469

470

471

472

473

474

475

476

477

478

479

480

481

482

483

484

485

486

487

488

489

490

491

492

493

494

495

496

497

498

499

contaminant in 16 AOCs in the Great Lakes (Hartig and Thomas, 1988)

Dominant sources: Terrigenous sources including sedimentary rocks overlying the Canadian Shield above Lake Superior (Fig. 1), weathering, mining

Background and relevance to the Great Lakes: $\operatorname{Iron}(\mathrm{Fe})$ is the $4^{\text {th }}$ most abundant element in the Earth's crust ( $7 \%$ or $70,000 \mathrm{ppm})$ and is believed to be the most abundant element on Earth. $\mathrm{Fe}$ is essential to the biological function of all animals (Hampel, 1968c; Williamson, 1999b). Some Fe bearing minerals are the result of Thiobacillus reactions, which oxidize Fe in aqueous solution. Fe can scavenge trace metals and bring them out of solution, but it can also carry those same trace metals back into solution under acidic or reducing conditions. Increased Fe levels in surface waters can increase algal productivity, especially of cyanobacteria which have higher $\mathrm{Fe}$ requirements than eukaryotic algae. Fe becomes accessible to algae in anoxic sediments, which transform it into $\mathrm{Fe}^{2+}$, an ion suitable for algal uptake (Verschoor et al., 2017). In some cases in the Great Lakes, Fe has the potential to be a limiting nutrient in the formation of algal blooms (North et al., 2007). The most important Fe-producing district in the United States is the Mesabi Range within the Lake Superior Watershed, where there was intense taconite processing during the 1960s and 1970s. The Reserve Mining Company in Silver Bay, Minnesota discharged taconite tailings directly into Lake Superior. In sediment cores Fe, like Mn, is a mobile element under reducing conditions which can concentrate at the sediment-water interface. Shaw Chraïbi et al. (2014) found increasing concentrations in their core from the eastern watershed of Lake Superior between 1850 and 1890. In the western watershed they found increases around 1880, with a peak around 1930. Kemp and Thomas (1976b) found Fe levels in their sediment cores from Lakes Ontario, Erie, and Huron remained fairly stable except in Lake Erie, which showed increases near the surface, possibly due to anthropogenic inputs from steel plants of Detroit and Cleveland. Yuan (2017) also found surface enrichments in their sediment cores from the Sandusky Bay of Lake Erie, likely due to a combination of anthropogenic loading and redox driven migration of Fe near the sediment surface.

Cobalt

Contaminant status in the Great Lakes: Yes, from mining, fossil fuel combustion, and other industrial sources

Dominant sources: Natural bedrock sources, mine tailings, industry, fossil fuels Background and relevance to the Great Lakes: Cobalt (Co) has an average crustal concentration of $25 \mathrm{ppm}$ (Taylor, 1964). Atmospheric releases of Co are expected to be mostly from natural sources such as windblown soil, forest fires, and volcanoes. Increased Co levels in water may be attributed to anthropogenic sources including mining, the burning of fossil fuels, vehicular exhaust, and the use of phosphate fertilizers (ASTDR, 2004b). According to Smith \& Carson (1981) Lake Huron received 76\% of its Co from natural sources and Lake Superior received $85.4 \%$. Concentrations of Co are increased in mine tailings of the Keweenaw Peninsula (Lake Superior) and are also waste contaminants related to the production of alloys and metal coating processes (Jeong \& McDowell, 2003; Reavie et al., 2005). It is a redox sensitive element much like $\mathrm{Mn}$ and $\mathrm{Fe}$ and can migrate to the top of sediment cores (Yuan, 2017). Kemp et al. (1978) found uniform concentrations of Co in their cores from Lake Superior and Lake Huron with minor anthropogenic enrichments at some sites. 
500

501

502

503

504

505

506

507

508

509

510

511

512

513

514

515

516

517

518

519

520

521

522

523

524

525

526

527

528

529

530

531

532

533

534

535

536

537

538

539

540

541

542

Nickel

Contaminant status in the Great Lakes: Yes, listed as a sediment contaminant or water contaminant in 16 AOCs in the Great Lakes (Hartig and Thomas, 1988)

Dominant sources: Greenstone belts in the Archean rocks north of Lake Superior (Fig. 1), steel mills, coal-fired power plants, mining, and other industries

Background and relevance to the Great Lakes: Nickel $(\mathrm{Ni})$ is the $24^{\text {th }}$ most abundant element in the Earth's crust and is more abundant than $\mathrm{Cu}, \mathrm{Zn}$, and $\mathrm{Pb}$ combined. There are naturally low levels of Ni in surface water (ASTDR, 2005a), and it has toxicity only related to industrial exposure (Adamec \& Springer, 1968). There are respiratory, immune system, and birth issues linked to workers in refineries (ASTDR, 2005a). Cole et al. (1990) found increased Ni in a peat core in Northern Indiana, downwind of Chicago, related to steel mills and coal-fired plants. Kemp et al. (1978) found high anthropogenic inputs of Ni in Lake Huron related to contamination from the Ni mining complex in the Sudbury area. This contamination did not extend to Lake Superior, and the authors theorized that this is due to minimal atmospheric contamination and little migration in pore water. In Lake Superior, Nussmann (1965) also found low, natural Ni content in sediments that was concentrated in the clay size fraction. Walters, Wolery \& Myser (1974) noted enrichment in their cores of Lake Erie related to electroplating facilities in the Cleveland area, particularly during the late $1940 \mathrm{~s}$.

\section{Copper}

Contaminant status in the Great Lakes: Yes, listed as a sediment contaminant or water contaminant in 31 AOCs in the Great Lakes (Hartig and Thomas, 1988)

Dominant sources: Precambrian Shield underlying Lake Superior (Fig. 1; Kolak et al.,1999), mining, wastewater, and other industries

Background and relevance to the Great Lakes: Copper $(\mathrm{Cu})$ is the $26^{\text {th }}$ most abundant element in the Earth's crust (Williamson, 1999a). It is a necessary nutrient for plants, animals, and bacteria, though it is toxic at high concentrations (Grinstead, 1968). Because it is harmless or even beneficial at low concentrations, Kolak et al. (1998) consider it a noncritical contaminant, a group of anthropogenically enriched elements that are considered lower priority for contaminant loading reduction than elements that are toxic at lower concentrations. According to ASTDR (2004c), waste water is the biggest anthropogenic source of $\mathrm{Cu}$ in waterways, and considerable amounts of $\mathrm{Cu}$ remain in effluent. They calculate that runoff from natural weathering and disturbed sediment accounts for $68 \%$ of $\mathrm{Cu}$ in natural waters. $\mathrm{Cu}$ has been mined for more than 6,000 years (Peretti, 1968). Ore deposits in the Keweenaw Peninsula (Lake Superior) were discovered in the 1840s, though evidence of $\mathrm{Cu}$ mining on Isle Royale goes back 6,500 years before present (Pompeani et al., 2015). Between 1850 and 1929 the Keweenaw district was the $2^{\text {nd }}$ largest producer of $\mathrm{Cu}$ in the world (Kerfoot et al., 2016). Cu concentrations above background levels have been found in all of the Great Lakes, whether due to wastewater effluent, mining, or industry, though the levels are decreasing in more recent times, potentially due to legislation and better containment of industrial wastes (Kemp et al., 1976; Kemp et al., 1978; Kolak et al., 1998). In their sediment cores of Lake Superior, Kolak et al. (1999) surmised Cu in the nearshore sediments were related to mining discharge and that offshore was related instead to biological uptake and settling of organic matter. Yuan (2017) also found $\mathrm{Cu}$ correlated with organic matter in their surficial sediments from Lake Erie. Kerfoot et al. (1999) determined less

Peer] reviewing PDF | (2020:01:44690:1:0:NEW 22 Mar 2020) 
543 than $10 \%$ of the $\mathrm{Cu}$ loading into Lake Superior was atmospheric, although atmospheric

544 deposition is a source of many other metals into the lake.

545 Zinc

546 Contaminant status in the Great Lakes: Yes, listed as a sediment or water contaminant in 30

547 AOCs in the Great Lakes-St. Lawrence River system (Hartig and Thomas, 1988)

548 Dominant sources: Mafic and felsic volcanic rocks overlying the Greenstone belts in Archaean

549 rocks north of Lake Superior (Fig. 1), erosion, urban runoff, mine drainage, other industrial

550 sources.

551 Background and relevance to the Great Lakes: $\mathrm{Zinc}(\mathrm{Zn})$ is one of the most widely used

552 metals in the world. Though $\mathrm{Zn}$ is essential to human life it can be toxic at high concentrations.

$553 \mathrm{Zn}$ deficiency and excess can result in problems with metabolism and organ function in humans

554 (Nriagu, 2011). It has been mined extensively and is released into the atmosphere from mining,

555 iron and steel production, and coal and fuel combustion. It is released into waterways through

556 erosion, urban runoff, mine drainage, and municipal and industrial effluent (ASTDR, 2005b).

557 Sources of $\mathrm{Zn}$ pollution in urban environments include galvanized steel and automotive exhaust

558 (Chambers et al., 2016). It has been found enriched in post-settlement surface layers of sediment

559 cores throughout the Great Lakes, and authors agree that its sources are largely anthropogenic

560 (Förstner, 1976; Goldberg et al., 1981; Kemp \& Thomas, 1976a; Kemp \& Thomas, 1976b;

561 Kemp et al., 1978; Marvin et al., 2003; McKee et al., 1989; Nussmann, 1965; Painter et al.,

562 2001; Reavie et al., 2005; Yuan 2017). In their cores of Lake George (between lakes Superior

563 and Huron), Reavie et al. (2005) attributed $\mathrm{Zn}$ to the production of alloys and metal coating

564 processes. Goldberg et al. (1981) concluded $\mathrm{Zn}$ in Lake Michigan came primarily from the iron

565 and steel industry. Förstner (1976) found major increases in Zn between 1939 and 1955 related

566 to the growth of industry during World War II and the Korean conflict.

567 Yttrium

568 Contaminant status in the Great Lakes: None known

569 Dominant sources: Minerals containing rare-earth elements

570 Background and relevance to the Great Lakes: Yttrium (Y) is the $28^{\text {th }}$ most abundant element

571 in the Earth's crust, occurring at an average of $30 \mathrm{ppm}$. It is twice as abundant as lead. It is found

572 in all rare earth minerals and is sometimes classified with them, although it is not technically part

573 of the group (Emsley, 2002). It is very chemically similar to the rare earth elements and was

574 formed in the Earth's crust by the same geochemical processes (Daane, 1968). Y has no known

575 biological role, though it does occur in all species. It has no apparent toxicity and poses no

576 environmental threat to plants or animals. To date, Y has not been studied in the Great Lakes

577 except as ${ }^{90} \mathrm{Y}$ in water, a short-lived decay byproduct of ${ }^{90} \mathrm{Sr}$ generated as nuclear waste (Amiro,

578 1993).

579 Zirconium

580 Contaminant status in the Great Lakes: None Known

581 Dominant sources: Soil dust

582 Background and relevance to the Great Lakes: Zirconium ( $\mathrm{Zr}$ ) is a lithogenic element that is

583 immobile in the sediments and resistant to weathering (Boës et al., 2011; Förstner \& Wittmann, 
584 1979; Schaetzl, Mikesell \& Velbel, 2006). While little studied, Zr seems to have very low 585 toxicity (McClain, 1968). In sediment cores it is largely associated with soil dust, which is 586 mostly atmospherically transported. Nussmann (1965) found Zr in Lake Superior was

587 concentrated in the fine silt and was not related to biological activity or organic matter.

588 Niobium

589 Contaminant status in the Great Lakes: None known

590 Dominant sources: Minerals containing rare-earth elements

591 Background and relevance to the Great Lakes: Niobium $(\mathrm{Nb})$ is the $33^{\text {rd }}$ most abundant 592 element in the Earth's crust (Emsley, 2002). It generally occurs with Ta and the rare-earth 593 elements (Schmidt, 1968). It is very similar to Ta in physical, chemical, and electric properties. 594 Niobium is used in the production of high-strength, low-alloy steel and super alloys. It is used in 595 high-pressure pipeline construction and the auto industry (Mackay and Simandl, 2014). Nb has 596 not been studied in the Great Lakes.

597 Molybdenum

598 Contaminant status in the Great Lakes: Likely

599 Dominant sources: Steel mills and other industrial sources

600 Background and relevance to the Great Lakes: Molybdenum (Mo) is the $54^{\text {th }}$ most abundant

601 element in the Earth's crust and averages around 2 ppm in soils (Emsley, 2002). It is used in steel

602 making and is found in higher concentrations near mills, industrial sources, and uranium mines

603 (Alloway, 2013a; Giussani, 2011). It is also found in waste water sludge. Mo is an essential trace 604 element in all species, and it is critical for nitrogen fixation in plants. It is generally

605 toxicologically harmless in humans (Sigel, Sigel \& Sigel, 2013). Shahin, Paode \& Holsen (2000)

606 found significantly higher atmospheric fluxes of Mo near urban sites than more remote sites

607 around Lake Michigan. Yuan (2017) found significantly elevated concentrations of Mo in cores

608 of Lake Erie after 1950 attributed to anthropogenic sources.

609 Cadmium

610 Contaminant status in the Great Lakes: Yes, listed as a sediment contaminant or water

611 contaminant in 11 AOCs in the Great Lakes (Hartig and Thomas, 1988)

612 Dominant sources: Industrial releases

613 Background and relevance to the Great Lakes: Cadmium $(\mathrm{Cd})$ is a toxic element on the 614 United Nations Environmental Program's list of top 10 hazardous pollutants and is a priority 615 pollutant according to the United States Environmental Protection Agency (Emsley, 2002; 616 Mudhoo, Garg \& Wang, 2012). It is the $65^{\text {th }}$ most abundant element in the Earth's crust at 0.1 $617 \mathrm{ppm}$. In soil, Cd averages $1 \mathrm{ppm}$, though polluted soil has been found to contain up to 1,500 $618 \mathrm{ppm}$. Cd is thought to be completely non-essential for biological function (Smolders \& Mertens, 619 2013; Tchounwou et al., 2012). Cd bioaccumulates and is a particular concern in plants, where it 620 accumulates in leaves and is consumed by animals or humans (Nagajyoti, Lee \& Sreekanth, 621 2010). It is also believed to be carcinogenic. Cd is used in electroplating steel and in 622 rechargeable nickel-Cd batteries. It is a known atmospheric contaminant, being released by 623 smelting, fossil fuel burning, and waste incinerations (Norton et al., 2007). Due to greater 624 recognition of its toxicity and increased regulations, anthropogenic $\mathrm{Cd}$ emissions have decreased 
625 over $90 \%$ in the last 50 years since elemental alternatives were identified in the 1960s (ASTDR,

626 2012a). Cd was found to be anthropogenically enriched in sediment cores throughout the Great

627 Lakes (Förstner, 1976; Goldberg et al., 1981; Kemp \& Thomas, 1976a; Kemp \& Thomas, 1976b;

628 Kemp et al., 1978; Marvin et al., 2003; Reavie et al., 2005; Walters, Wolery \& Myser, 1974;

629 Yuan, Depew \& Soltis-Muth, 2014; Yuan, 2017). Förstner (1976) attributed Cd in sediment

630 cores from Lake Erie to industrial discharges and specifically found high enrichments in the late

631 1940s corresponding to the growth of the Cleveland electroplating industry. Reavie et al. (2005)

632 associated $\mathrm{Cd}$ in a Lake George sediment core with production of alloys, metal coating

633 processes, and leather tanning in the area of Sault Ste Marie. They found decreases in the

634 sediments since the late 1950s, when Northwestern Leather Company closed.

\section{Hafnium}

636 Contaminant status in the Great Lakes: None known

637 Dominant sources: Zr containing minerals and soil dust

638 Background and relevance to the Great Lakes: Hafnium (Hf) is the $45^{\text {th }}$ most abundant

639 element in the Earth's crust at 5.3 ppm. In soils, it averages around 5 ppm, ranging from 2-20

$640 \mathrm{ppm}$. Hafnium has no known biological role or toxicity. Hf is used as a control rod for nuclear

641 reactors and submarines because it effectively absorbs neutrons, but otherwise it has limited

642 applications. It is not known to be an environmental threat (Emsley, 2002; Hampel, 1968b).

643 Kerfoot and Robbins (1999) found Hf concentrations to be moderately enriched in the Point

644 Mills stamp sands on Lake Superior.

\section{Tantalum}

646 Contaminant status in the Great Lakes: None known

647 Dominant sources: Occurs with Nb and the rare-earth elements in clay and shale

648 Background and relevance to the Great Lakes: Tantalum (Ta) is the $51^{\text {st }}$ most abundant

649 element in the Earth's crust at an average of 2 ppm. It is insoluble and there is virtually no Ta in

650 natural waters (Emsley, 2002), so in geochemical records it would be expected to be associated

651 with mineral particulates. Ta has no biological role and is not known to have toxicity properties,

652 hence it is widely used in surgical tools (Wehrmann, 1968). It is an essential metal in modern

653 society and is also used for corrosion resistance, microelectronics, and high-strength, low-alloy

654 steel (Mackay \& Simandl, 2014). This element has not been studied in the Great Lakes.

\section{Mercury}

656 Contaminant status in the Great Lakes: Yes, related to coal fired power plants, mining, and

657 other industries

658 Dominant sources: Atmospheric

659 Background and relevance to the Great Lakes: Mercury $(\mathrm{Hg})$ is relatively rare; at $50 \mathrm{ppb}$ in

660 the Earth's crust, it is the $68^{\text {th }}$ most abundant element (Emsley, 2002). In soil it averages 0.01-

$6610.5 \mathrm{ppb}$, though contaminated soils have up to $0.2 \mathrm{ppm}$. Despite its overall rarity, it is an element

662 of major concern because its toxicity at very low concentrations threatens environmental and

663 human health. Because harmful levels of $\mathrm{Hg}$ can be very low, analytical techniques for $\mathrm{Hg}$

664 require an especially low detection limit, much lower than that required for most other metallic

665 elements. Hg has no known biological role but is present in all life. It is a potent neurotoxin that 
666 accumulates and magnifies in aquatic food webs (Sherman et al., 2015). Hg is a pollutant 667 throughout the Great Lakes, and most water bodies in the Great Lakes region have fish 668 consumption advisories due to $\mathrm{Hg}$ accumulation in tissues (Risch et al., 2012). As a contaminant 669 of concern, much research has been performed on Hg levels in Great Lakes sediment and sediment cores (Table 1). Sediment cores reveal Hg increases beginning in the mid-1800s and reaching a maximum in the 1970 s, decreasing in more recent times with increasing regulation

672 and phasing out of most uses in modern industry (Steinnes, 2013). In modern times, $\mathrm{Hg}$ is

673 released into the atmosphere primarily by coal-fired power plants, metal processing, and waste

674 incineration (Chambers et al., 2016; USDOI \& USGS, 2017). Historic Hg atmospheric emissions

675 had peaks in 1879 and 1920 from gold and silver mining (Pirrone et al., 1998). Diffuse atmospheric sources are thought to dominate Great Lakes Hg, but there have been a number of localized point sources. Around the Keweenaw Peninsula (Superior), Hg loading was greatly enhanced during the height of $\mathrm{Cu}$ mining between 1880 and 1930 due to its presence in tailing piles, smelters, mills, and parent ores (Kerfoot et al., 1999; Kerfoot et al., 2004; Kerfoot et al., 2016). High loadings were found near pulp and paper plants near Thunder Bay, Nipigon, and Munising (Fitchko \& Hutchinson, 1975; Kemp et al., 1978). In Lake Erie, major increases in $\mathrm{Hg}$

682 releases were seen around 1939 and 1954, corresponding with establishment and growth of two chlor-alkali facilities (Azcue, Rosa Mudroch, 1996; Wolery \& Walters, 1974).

684

685

Lanthanides

686

Dominant Sources of Rare Earth Elements: The term "rare earth" is somewhat of a

687 misnomer, as they are not actually rare on Earth but they do appear together. The bulk of the lanthanides are found in eroded material in clay and shale, such as that in the Paleozoic province surrounding Lakes Michigan, Erie, and Ontario (Fig. 1). A very small percent is dissolved into solution. These elements take part in almost no chemical processes. Mobilization may occur during weathering but not likely during erosion and transport. Overall, there are minimal postdepositional changes in sedimentary records (Fleet, 1984).

\section{Lanthanum}

694 Contaminant status in the Great Lakes: None known but potential

695 Dominant sources: Weathering of clay and shale

696 Background and relevance to the Great Lakes: Lanthanum (La) is the $28^{\text {th }}$ most abundant element at $32 \mathrm{ppm}$ in the Earth's crust and approximately $26 \mathrm{ppm}$ in soil (Emsley, 2002). La has been shown to be toxic in a number of organisms, and anthropogenic loadings have been found in several German rivers (Kulaksiz \& Bau, 2011b). In sediment cores of the Great Lakes, Reavie et al. (2005) and Shimp et al. (1971) found little or no variation in concentration from preindustrial sediments to modern times. Olivarez, Owen \& Long (1989) and Neustadter, Fordyce \& King (1976) noted that the concentration of La in Great Lakes sediments was controlled by inputs of crustal sediments. However, Herrmann et al. (2016) highlight La's potential role as an

704

705 emerging contaminant of concern with its use in innovative technologies such as superconductors, catalysts, lasers, and batteries, and an increase in releases to aquatic environments. 
706 Cerium

707 Contaminant status in the Great Lakes: None known but potential

708 Dominant sources: Weathering of clay and shale

709 Background and relevance to the Great Lakes: Cerium $(\mathrm{Ce})$ is the $25^{\text {th }}$ most abundant element

710 in the Earth's crust at 68 ppm, averaging 50 ppm in soil (Emsley, 2002). Ce is the most abundant

711 of the rare earth elements. It has no biological role and, like all rare earth elements, has low acute

712 toxicity (Gschneidner, 1968). Ce is found in urban environments due to its use in welded metal

713 plating (Chambers et al., 2016). It has found more modern uses in long-life, low-energy

714 lightbulbs and as a vehicular exhaust cleaner. Ce has been suggested as a reference element in

715 the sediment to account for soil influences so that the percentage of actual anthropogenic influx

716 can be measured. Ce has a radioactive isotope, ${ }^{144} \mathrm{Ce}$, which is produced in nuclear reactors and

717 was detected in Lakes Superior and Huron in 1974 and 1975 (Durham \& Joshi, 1984; Tracy \&

718 Prantl, 1983). Reavie et al. (2005) found paleolimnological Ce concentrations in a Lake George

719 core did not change over the most recent two centuries.

720 Praseodymium

721 Contaminant status in the Great Lakes: None known

722 Dominant sources: Weathering of clay and shale

723 Background and relevance to the Great Lakes: Praseodymium (Pr) is the $39^{\text {th }}$ most abundant

724 element in the Earth's crust at $9.5 \mathrm{ppm}$. It is a rare earth element and occurs in minerals

725 exclusively with other members of the group. There is no documented environmental threat from

726 this element. It can also exist as a fission product of U, Th, and Pu (Eyring, 1968; Emsley, 2002).

727 Neodymium

728 Contaminant status in the Great Lakes: None known

729 Dominant sources: Weathering of clay and shale

730 Background and relevance to the Great Lakes: Neodymium $(\mathrm{Nd})$ is the $26^{\text {th }}$ most abundant

731 element in the Earth's crust and the $2^{\text {nd }}$ most abundant rare-earth element after Ce. $\mathrm{Nd}$ is almost

732 as abundant as $\mathrm{Cu}$ at $38 \mathrm{ppm}$ in the Earth's crust and around $20 \mathrm{ppm}$ in soils. It has no known

733 biological role or environmental threat (Emsley, 2002).

734 Samarium

735 Contaminant status in the Great Lakes: None known but potentially an emerging contaminant

736 of concern

737 Dominant sources: Weathering of clay and shale

738 Background and relevance to the Great Lakes: Samarium (Sm) is the $40^{\text {th }}$ most abundant

739 element in the Earth's crust at $8 \mathrm{ppm}$. Sm is found with other rare-earth elements (Emsley,

740 2002). Sm has no known biological role, though anthropogenic Sm was found to be bioavailable

741 to freshwater clams (Merschel \& Bau, 2015), and toxicity is uncertain. Sm is an emerging

742 contaminant of concern in river systems. It is used for high-strength permanent magnets and for

743 control rods in nuclear reactors. In the Rhyne River in Germany, a significant amount of Sm

744 pollution was found downstream from a production plant for fluid catalytic cracking (Kulaksiz \&

745 Bau, 2013). No pollution is currently known in the Great Lakes region, and in sediment cores 
746 from Lake George Reavie et al. (2005) found no changes in Sm concentration over two

747 centuries, indicating solely natural sources.

748 Europium

749 Contaminant status in the Great Lakes: None known

750 Dominant sources: Weathering of clay and shale

751 Background and relevance to the Great Lakes: Europium (Eu) is the $50^{\text {th }}$ most abundant

752 element in the Earth's crust at $2 \mathrm{ppm}$. It is one of the most abundant of the rare earth elements. It

753 appears to have no biological role or pose any environmental threat (Emsley, 2002). It is the

754 most reactive of the rare earth metals and is used for the red phosphor in cathode ray color

755 televisions and fluorescent lamps (Thompson, 1968). Reavie et al. (2005) found Eu in their

756 sediment cores did not vary with sediment depth or composition and Neustadter, Fordyce \&

757 King (1976) considered atmospheric Eu over the Great Lakes to be soil derived.

758 Gadolinium

759 Contaminant status in the Great Lakes: None known but potentially an emerging contaminant

760 of concern

761 Dominant sources: Weathering of clay and shale

762 Background and relevance to the Great Lakes: Gadolinium (Gd) is the $41^{\text {st }}$ most abundant

763 element in the Earth's crust. It is one of the more abundant rare earth elements at an average of 8

$764 \mathrm{ppm}$. No acute health effects are known, but potential long-term effects of low-level exposure are

765 possible (Kulaksız \& Bau, 2011a). Gd has been used as a contrasting agent in magnetic

766 resonance imaging since 1988. It is not removed by wastewater treatment plants and is an

767 emerging micropollutant of concern in surface waters in densely populated areas. Gd chelates

768 can be used as tracers for other emerging microcontaminants that are not removed in wastewater

769 treatment processing, such as steroids and pharmaceuticals. Bau, Knappe \& Dulski (2006) found

770 increased Gd levels in the surface water of Lake Erie and the Niagara River, suggesting input

771 from the urban area of Buffalo.

772 Terbium

773 Contaminant status in the Great Lakes: None known

774 Dominant sources: Weathering of clay and shale

775 Background and relevance to the Great Lakes: Terbium (Tb) is the $57^{\text {th }}$ most abundant

776 element in the Earth's crust at 1 ppm. It is one of the rarer rare-earth elements and occurs in

777 minerals with the others of that group. Tb does not have many uses, as it is very expensive to

778 acquire and separate from the other rare-earths, but it is used in lasers and low-energy lightbulbs

779 (Emsley, 2002). It has no known biological role and is not considered an environmental threat.

780 Dysprosium

781 Contaminant status in the Great Lakes: None known

782 Dominant sources: Weathering of clay and shale

783 Background and relevance to the Great Lakes: Dysprosium (Dy) is the $42^{\text {nd }}$ most abundant

784 element in the Earth's crust at 6 ppm. It is a rare-earth element and is found associated with the

785 other rare-earth elements in minerals. It has no biological role and low acute toxicity (Emsley,

786 2002; Powell, 1968). Kerfoot \& Robbins (1999) found that Dy showed modest enrichment in the 
787 stamp sands submerged in waterways of the Keweenaw Peninsula over background

788 concentration. Due to its extremely low background level in Lake Michigan, McCown (1979)

789 used Dy to tag experimental simulated oily waste in order to determine its motion in freshwater.

790 Holmium

791 Contaminant status in the Great Lakes: None known

792 Dominant sources: Weathering of clay and shale

793 Background and relevance to the Great Lakes: Holmium (Ho) is one of the rarer rare-earth

794 elements at $1.4 \mathrm{ppm}$ in the Earth's crust and $\sim 1 \mathrm{ppm}$ in soils. It has no biological role and poses

795 no environmental threat. Ho has the highest magnetic strength of any element (Emsley, 2002). In

796 a sediment core of Lake Superior, Korda et al. (1977) found Ho concentrations varied between

$797 \quad 0.7$ and $1.4 \mathrm{ppm}$ and had no apparent anthropogenic component.

\section{Erbium}

799 Contaminant status in the Great Lakes: None known

800 Dominant sources: Weathering of clay and shale

801 Background and relevance to the Great Lakes: Erbium (Er) is one of the more abundant rare-

802 earth elements at $4 \mathrm{ppm}$ in the Earth's crust and $\sim 1.6 \mathrm{ppm}$ in soil (Emsley, 2002). It has no

803 biological role and poses no environmental threat. Korda et al. (1977) found Er concentrations

804 between 1.8 and $3.1 \mathrm{ppm}$ in their core of Lake Superior.

805 Thulium

806 Contaminant status in the Great Lakes: None known

807 Dominant sources: Weathering of clay and shale

808 Background and relevance to the Great Lakes: Thulium (Tm) is the second rarest rare-earth

809 element after promethium at $0.5 \mathrm{ppm}$ in the Earth's crust and an average of $0.5 \mathrm{ppm}$ in soil.

810 Mayfield \& Fairbrother (2015) examined the concentrations of rare-earth elements in the tissues

811 of various freshwater fish, and $\mathrm{Tm}$ was the only element that was not detectable in the species

812 examined.

813 Ytterbium

814 Contaminant status in the Great Lakes: None known

815 Dominant sources: Weathering of clay and shale

816 Background and relevance to the Great Lakes: Ytterbium $(\mathrm{Yb})$ is one of the rarer rare-earth

817 elements at $3 \mathrm{ppm}$ in the Earth's crust and around $2 \mathrm{ppm}$ in soil. It has no biological role and

818 does not pose an environmental threat (Emsley, 2002). In an undated sediment core from western

819 Lake Superior, Korda et al. (1977) found concentrations of Yb ranged from 1.6 to $3.1 \mathrm{ppm}$. In

820 cores of Lake George, Reavie et al. (2005) found $\mathrm{Yb}$ concentrations did not vary over time or by

821 sediment composition, indicating that natural sources were dominant, although Kerfoot and

822 Robbins (1999) found moderate enrichment of $\mathrm{Yb}$ in the stamp sands of Lake Superior.

\section{Lutetium}

824 Contaminant status in the Great Lakes: None known

825 Dominant sources: Weathering of clay and shale

826 Background and relevance to the Great Lakes: Lutetium ( $\mathrm{Lu})$ is one of the rarer of the rare 
827 earth elements at $0.5 \mathrm{ppm}$ in the Earth's crust. Lu has no known biological role and is thought to 828 pose no environmental threat. $\mathrm{Lu}$ is found in minerals that contain all of the lanthanides (Emsley, 829 2002). In their sediment cores of Lake George, Reavie et al. (2005) found that Lu did not vary

830 with sediment depth or composition, showing no anthropogenic changes in Lu downstream from 831 Lake Superior.

832

833 Basic Metals

834 Aluminum

835 Contaminant status in the Great Lakes: Some historical contamination associated with

836 taconite tailings in the western part of Lake Superior

837 Dominant sources: Feldspars and clay minerals, runoff and erosion

838 Background and relevance to the Great Lakes: Aluminum (Al) is the most abundant metal 839 (7\%) in the Earth's crust (Khan et al., 2013). Al has a strong sorption tendency, binding strongly 840 to clay minerals and natural organic matter (Lum and Leslie, 1983; Driscoll, 1985). Al is not 841 known to be a nutrient for any plants or animals (Discroll and Schecher, 1990). Elevated 842 concentrations of ionic $\mathrm{Al}$ are also important because $\mathrm{Al}$ acts as a buffer and influences the

843 cycling of elements such as $\mathrm{P}$ and $\mathrm{C}$ through adsorption and coagulation reactions (Driscoll and

844 Schecher, 1990). It is highly insoluble and unreactive under most conditions, but below a pH of 6

$845 \mathrm{Al}$ can dissolve from substrates and become available in its ionic form, at which point it becomes

846 bioavailable and can be toxic (Bache, 1986). Ionic $\mathrm{Al}$ is released in acidic waters often related to

847 acid rain and acid mine drainage (ATSDR, 2008). Fluxes in total Al in lakes and streams are

848 virtually all associated with sediment transport and runoff and erosion (Driscoll, 1989; Norton,

849 Binford \& Kahl, 1992; Long et al., 2010). Lakes are sinks for Al because of their acid

850 neutralizing capacity (Driscoll, 1989), so toxic levels of Al in the Great Lakes are unlikely.

851 Spikes in overall Al levels in sediment cores are often associated with land clearing and logging

852 (Selig, Leipe \& Dörfler, 2007), which expose clay/Al-bearing soils to erosion. In Lake Superior,

853 both Kemp et al. (1978) and Shaw Chraïbi et al. (2014) saw an increase in Al correlated with the

854 input of taconite tailings between 1955 and 1967. According to Oxberry, Doudoroff \& Anderson

855 (1978), Al from fresh taconite tailings is not soluble in Lake Superior waters, which are slightly

856 alkaline and have a $\mathrm{pH}$ generally above 7.3 , so there was not likely to be toxicity effects. In

857 sediment cores taken from Lakes Ontario, Erie, and Huron, Kemp and Thomas (1976b) found

858 the concentration of $\mathrm{Al}$ to remain generally uniform over the period from pre-settlement to the

859 early 1970s.

860 Gallium

861 Contaminant status in the Great Lakes: None known but possible

862 Dominant sources: Clay minerals, coal fly ash

863 Background and relevance to the Great Lakes: Gallium $(\mathrm{Ga})$ is more abundant than $\mathrm{Pb}$ in the

864 Earth's crust, averaging $18 \mathrm{ppm}$, but unlike $\mathrm{Pb}, \mathrm{Ga}$ is not concentrated in any minerals, so it is

865 more difficult to obtain using industrial processes (Emsley, 2002). Some Ga is incorporated in

866 clay minerals, and it can substitute for $\mathrm{Al}$ in sediments (Nussmann, 1965). Ga is recovered as a

867 byproduct of processing $\mathrm{Zn}$ ores and bauxite and is used in microchips, lasers, solar cells, and 
868 LEDs (USDOI \& USGS, 2017). Ga has no biological role, and Reid, Rengel \& Smith (1996)

869

870

871

872

873

874

875

876

877

878

879

880

881

882

883

884

885

886

887

888

889

890

891

892

893

894

895

896

897

898

899

900

901

902

903

904

905

906

907

908

909 demonstrated Ga toxicity to green algae, though they found it to be less toxic than Sc and Al. Ga averages 7 ppm in coal, but in coal ash, Ga averages 100 ppm (Blowes et al., 2014). In surficial sediments from Lake Michigan, Cahill (1981) found Ga concentrations from 0-20 ppm. Nussmann (1965) found Ga in Lake Michigan averaged 19-22 ppm, and Ga content of Lake Superior sediments averaged $13.2 \pm 5.4 \mathrm{ppm}$, seeming to increase slightly near the top of the sediment cores, though this increase was not statistically significant.

Tin

Contaminant status in the Great Lakes: Yes, attributed to industry and fossil fuel emissions Dominant sources: Largely atmospheric emissions from smelting Background and relevance to the Great Lakes: Tin (Sn) is the $49^{\text {th }}$ most abundant element in the Earth's crust at $2 \mathrm{ppm}$. It averages around $1 \mathrm{ppm}$ in soil. Sn is insoluble and its ore is very resistant to weathering, so the amount of $\mathrm{Sn}$ in soil and natural waters is low (Emsley, 2002). There is some evidence that it might be an essential micronutrient in mammals, though it is also a part of compounds which are enzyme disruptors in aquatic organisms (Alloway, 2013b). Some of its uses include plating cans and containers, solder, and fungicides (Blowes et al., 2014), and it has become an anthropogenic contaminant in natural systems. Robbins (1980) found $\mathrm{Sn}$ to be $2^{\text {nd }}$ only to $\mathrm{Hg}$ in terms of enrichment in Southern Lake Huron. Biegalski \& Hopke (2004) determined that $\mathrm{Sn}$ in the atmosphere in the Great Lakes region was attributable to smelting. Goldberg et al. (1981) traced Sn sources in Lake Michigan to coal, coke and fuel oil, noting that it had similar profiles in sediment cores to charcoal. Yuan (2017) categorized Sn with the most enriched elements in Lake Superior sediments.

\section{Lead}

Contaminant status in the Great Lakes: Yes, related to fossil fuel emissions, mining Dominant sources: Leaded gasoline, shoreline bluffs of Lake Erie

Background and relevance to the Great Lakes: Lead $(\mathrm{Pb})$ is not a particularly abundant constituent in the Earth's crust; at $14 \mathrm{ppm}$, it is the $36^{\text {th }}$ most abundant element (Emsley, 2002). $\mathrm{Pb}$ is used as a proxy for human activity because it has a relatively low background concentration in sediments, averaging 23 ppm worldwide, with 18 ppm in Lake Erie (Azcue, Rosa \& Mudroch, 1996; Pompeani et al., 2013). $\mathrm{Pb}$ is a contaminant of particular interest because it is a cumulative poison that can damage organisms at low concentrations (Forsythe \& Marvin, 2009). Releases from anthropogenic sources, most notably as a fuel additive, dwarf those from natural sources (ASTDR, 2007c). The main current anthropogenic sources of $\mathrm{Pb}$ in the environment are mining and smelting, manufacture of $\mathrm{Pb}$ containing products, combustion of coal and oil, and waste incineration. As for all metals, natural sources of $\mathrm{Pb}$ from catchment soil and bedrock include fluvial and shoreline bluff erosion, such as that detailed by Kemp et al. (1976b) and Ritson et al. (1994) in Lake Erie. A great number of sediment cores have examined $\mathrm{Pb}$ concentrations in the Great Lakes over time (Table 1). It is enriched in surface sediments of all of the lakes due to anthropogenic activity. Rossmann, Pfeiffer \& Filkins (2014) found the following trends in Lake Michigan: in $1850 \mathrm{~Pb}$ levels increased above background levels correlated with coal and gas consumption. $\mathrm{Pb}$ loading increased with industrial activity during World War II and began to decline with the Clean Air Act of 1970 and the phasing out of leaded gasoline. According to 
910 Rossmann, Pfeiffer \& Filkins (2014), Lake Michigan loading in 1995 was 52\% lower than peak 911 loading in 1970. However, in the Sandusky Bay of Lake Erie, Yuan (2017) found only a 36\%

912 reduction from 1970 to 2010. Yohn et al. (2004) found that anthropogenic loading from the

913 1930s to the 1970s was mainly driven by regional sources such as leaded gasoline and since the

914 1970s has been much more closely correlated to local population density. This was attributed to

915 legacy pollution and $\mathrm{Pb}$ cycling, since $\mathrm{Pb}$ does not degrade in the sediments. Pompeani et al.

916 (2013, 2015) found periods of increased $\mathrm{Pb}$ loading in the Keweenaw Peninsula 8000-5000

917 years ago which they associated with $\mathrm{Cu}$ mining.

918

$919 \underline{\text { Semimetals }}$

920 Silicon

921 Contaminant status in the Great Lakes: Possibly some as dust

922 Dominant sources: Rocks, minerals, soils, dust

923 Background and relevance to the Great Lakes: Silicon ( $\mathrm{Si}$ ) is the second most common

924 element in the Earth's crust after oxygen. It makes up 28\% of Earth's crust and is the key

925 component of soil, occurring in almost all minerals (Emsley, 2002). Si is the third most abundant

926 element in the human body and is involved in bone mineralization. It is also a carcinogen and is

927 responsible for silicosis, a disease that occurs from inhalation of Si dust (Martin, 2013). Si never

928 occurs in sediments uncombined; it occurs either with oxygen as $\mathrm{SiO}_{2}$ (silica) or with oxygen and

929 metals as silicates (Lanning, 1968). Si is relatively unreactive and insoluble. Increases in $\mathrm{Si}$

930 concentration come from more intensive weathering of silicates and are associated with warmer

931 or wetter conditions. According to Chambers et al. (2016), Si levels are relatively high in some

932 urban waters due to its use in building materials such as clay and sandstone. Si was found to be a

933 conservative element that remained relatively constant in sedimentary records from Lakes

934 Ontario, Erie, Huron, and Superior (Kemp et al., 1976; Kemp et al.; 1978; Kemp \& Thomas,

935 1976a; Kemp \& Thomas, 1976b). Mudroch (1985) considered Si to be of terrigenous origin in

936 the Detroit River, and Holsen et al. (1993) also considered it a crustal element. In their core of

937 the western basin of Lake Superior, Shaw Chraibi et al. (2014) found peaks in Si around 1960

938 related to the period of taconite processing waste discharge in Silver Bay. Minerals containing

939 silica comprise more than $95 \%$ of the Earth's crust (ASTDR, 2017b). Silica, in the form of

940 quartz, is extremely resistant to weathering. In the form of other minerals, $\mathrm{SiO}_{2}$ is able to dissolve

941 in water to form bioavailable silicic acid, an important compound for biological use by some

942 plants and algae. In the Great Lakes, there is an inverse relationship between $\mathrm{SiO}_{2}$ concentration

943 and spring diatom population size, as diatoms take up all available $\mathrm{SiO}_{2}$ from the water column

944 (e.g. Lake Erie; Reavie et al., 2016). As the main component in cell walls of diatoms, biogenic

945 silica is a critical compound for algal communities. Schelske et al. (1987) used $\mathrm{SiO}_{2}$

946 concentrations in Lakes Michigan, Erie, and Ontario as indices of eutrophication because as P

947 loading increased, diatom production increased, eventually leading to $\mathrm{SiO}_{2}$ depletion and limited

948 diatom production. In modern times, the inverse is occurring in Lake Ontario, where $\mathrm{SiO}_{2}$ levels

949 are increasing as a symptom of the proliferation of invasive zebra and quagga mussels leading to

950 decreasing diatom populations (Dove, 2009). 
951 Arsenic

952 Contaminant status in the Great Lakes: Yes, listed as a sediment contaminant or water

953 contaminant in 10 AOCs in the Great Lakes (Hartig and Thomas, 1988)

954 Dominant sources: Mining and other industry, fossil fuel burning

955 Background and relevance to the Great Lakes: Arsenic (As) averages around $1.5 \mathrm{ppm}$ in the

956 Earth's crust and 1-10 ppm in soil (Emsley, 2002). It is a deadly poison and is carcinogenic

957 (Plant et al., 2014). As occurs naturally in soil and airborne dust and is associated with fine

958 particles (Sweet, Weiss \& Vermette, 1998). Anthropogenic releases of As are much higher than

959 natural releases and As ranks high on hazardous substances lists (ASTDR, 2007a). Arsenic's

960 primary use is as a wood preservative to prevent rot, though it was previously used as a

961 component of pesticides and fungicides. It is also associated with mining and smelting of $\mathrm{Cu}, \mathrm{Pb}$,

$962 \mathrm{Zn}$, and Sn and is present in coal and phosphate fertilizers. In the Great Lakes, As is associated

963 with ferromanganese nodules in Lake Michigan, particularly near Green Bay, and is released

964 with weathering and erosion. Increased As concentrations in aerosols over Lake Huron and Lake

965 Michigan have been related to fossil fuel use and smelters (Biegalski \& Hopke, 2004; Shahin,

966 Paode \& Holsen, 2000). Nriagu (1983) measured changes in As concentrations near smelters at

967 Sudbury Ontario that mirror $\mathrm{Cu}$ and Ni production. In Lake Superior, As was found increased

968 five fold in taconite, mine tailings, and the Freda stamp sands compared to a control area (Korda

969 et al., 1977). Reavie et al. (2005) found anthropogenically enriched As concentrations in post-

970 settlement sediments of Lake George, which they attributed to herbicide use. Förstner (1976) and

971 Walters, Wolery \& Myser (1974) saw major increases in Lake Erie sediments between 1939 and

972 1955, which they related to the growth of industry related to WWII and the Korean conflict.

973 Antimony

974 Contaminant status in the Great Lakes: Yes, related to mining and other industry

975 Dominant sources: Anthropogenic sources

976 Background and relevance to the Great Lakes: Antimony ( $\mathrm{Sb})$ is the $63^{\text {rd }}$ most abundant

977 element in the Earth's crust at $0.2 \mathrm{ppm}$. It has an average abundance of approximately $1 \mathrm{ppm}$ in

978 soil (Emsley, 2002). Sb has relatively low mobility in soils, has no biological role, and is highly

979 toxic. While naturally rare, $\mathrm{Sb}$ is anthropogenically enriched in soils and lakes. According to

980 Clemente (2013), Sb is enriched on the order of 70 times compared to background

981 concentrations in the United States. Sb contamination comes from mining and other activities

982 that result in releases of metal particles such as shooting ranges and brake dust (ASTDR, 2017a).

983 It is a priority pollutant according to the USEPA (Chen et al., 2003; Filella, Belzile \& Chen,

984 2002). Reavie et al. (2005) found Sb enriched in the sediment of Lake George related to the

985 production of alloys and metal coating processes in the adjacent watershed. Biegalski \& Hopke

986 (2004) found Sb highly enriched from crustal sources in aerosols over the north shore of Lake

987 Huron. Robbins (1980) determined Sb was the fourth most enriched pollutant in the surface

988 sediments of Lake Superior, after $\mathrm{Hg}$, $\mathrm{Sn}$, and $\mathrm{Pb}$. In Lake Erie, initial major increases in $\mathrm{Sb}$

989 concentrations occurred between 1948 and 1953 due to industrial uses and more diffuse sources

990 (Walters, Wolery \& Myser, 1974).

991 
992 Nonmetals

993 Phosphorus

994 Contaminant status in the Great Lakes: Yes, as a nutrient pollutant

995 Dominant sources: Agriculture, industry, sewage

996 Background and relevance to the Great Lakes: Phosphorus $(\mathrm{P})$ is one of the most widely

997 distributed elements. At 1,000 ppm in the Earth's crust, P is the $11^{\text {th }}$ most abundant element and

998 averages $1.5 \mathrm{ppb}$ in surface waters. $\mathrm{P}$ is necessary for all life, though in its elemental form $\mathrm{P}$ is

999 highly poisonous and reactive. In nature, $\mathrm{P}$ exists primarily as $\mathrm{PO}_{4}$ (Emsley, 2002; Whaley \&

1000 Currier, 1968). As a limiting nutrient for algal growth, anthropogenic P loading is a problem in

1001 natural waters such as the Great Lakes because too much P can support cultural eutrophication

1002 (Manning, Lum \& Birchall, 1983). Sources of anthropogenic P in urban environments include

1003 laundry detergent, fertilizer, food waste, and sewage (Chambers et al., 2016). Primarily as a

1004 response to increasing concerns about eutrophication, the United States and Canada implemented

1005 The Great Lakes Water Quality Agreement (Canada \& United States of America, 1972). Both

1006 countries implemented $P$ removal programs aimed at industrial and municipal point sources and

1007 reductions in phosphates in detergents (Baker et al., 2014). P levels have been a particular

1008 concern in Lakes Erie and Ontario. Lake Superior, the most oligotrophic of the Great Lakes, is

1009 thought to be P limited (Baehr \& McManus, 2003). Analyzing sedimentary P can be a poor

1010 indicator of actual $\mathrm{P}$ levels and eutrophication due to variable retention and post-depositional

1011 diagenesis. For this reason, diatom-inferred $\mathrm{P}$ levels are used to give a better picture of

1012 eutrophication, as they provide a surrogate measure of P levels that are not subject to these

1013 factors (Reavie, Heathcote \& Chraïbi, 2014). In an Eastern core of Lake Superior, Shaw Chraibi

1014 et al. (2014) found P levels peaked between 1990 and 1994. In the Western Core they found a

1015 peak in $\mathrm{P}$ around 1960, which they associated with taconite processing near Silver Bay. In

1016 sediment cores from Lakes Ontario, Huron, and Erie, Kemp \& Thomas (1976a and 1976b) found

1017 increases in P related to anthropogenic loading.

1018

1019 Actinide Series

1020 Thorium

1021 Contaminant status in the Great Lakes: Yes, part of the Port Hope Area of Concern

1022 Dominant sources: Naturally ubiquitous and a byproduct of $U$ mining and processing

1023 Background and relevance to the Great Lakes: Thorium (Th) is a typically radioactive metal

1024 which is ubiquitous in the environment, occurring naturally in the Earth's crust at concentrations

1025 between 8 and 12 ppm (ASTDR, 1990). Th is strongly adsorbed by clays, with a mean

1026 concentration of $30 \mathrm{ppm}$ in clay minerals (Langmuir \& Herman, 1980). Th is also generated as a

1027 byproduct of $U$ mining and processing. This can result in anomalously large, localized

1028 concentrations of Th in the environment that may be harmful. In the Port Hope Area of Concern

1029 (north shore of Lake Ontario), water quality and environmental health were threatened by Th

1030 contamination, a result of poor operation and waste management practices of Eldorado Mining

1031 and Refining between 1933 and 1953 (Government of Canada, 2017). An estimated 85,000-

103295,000 cubic meters of sediment containing radioactive material is present in this harbor in

Peer] reviewing PDF | (2020:01:44690:1:0:NEW 22 Mar 2020) 
1033 Ontario on the north shore of Lake Ontario. Sakaguchi et al. (2006) examined Th in the sediment 1034 records of Lake Baikal. They used Th as a proxy for terrestrial materials, as it has low solubility

1035 and is resistant to weathering. They found that it was enriched in the fine grain components of

1036 their core. In cores of Lake George, Reavie et al. (2005) found Th concentrations largely

1037 invariant with sediment composition and depth.

\section{Uranium}

1039 Contaminant status in the Great Lakes: Yes, part of the Port Hope Area of Concern

1040 Dominant sources: Ubiquitous, also associated with mining and nuclear power and weapons

1041 generation

1042 Background and relevance to the Great Lakes: Uranium (U) is present at 2 ppm in the Earth's

1043 crust and $0.7-11 \mathrm{ppm}$ in soil. In agricultural soil with phosphate fertilizer, the soil concentration

1044 averages $15 \mathrm{ppm}$. Coal combustion is also a significant source of $U$ in the environment. $U$ is

1045 ubiquitous and is found in most rocks and soils, though it is higher in rocks that are enriched in

$1046 \mathrm{Na}, \mathrm{K}$, or Si (Seaborg, 1968). It is naturally dominated by isotopic forms; ${ }^{238} \mathrm{U}$ accounts for $99 \%$

1047 of natural $U$ by mass. There is no known biological need for $U$, and it is both chemotoxic and a

1048 radiotoxic (Alloway, 2013c). $\mathrm{U}$ is mined and used for power generation and nuclear weapons,

1049 though it is naturally present in low concentrations in the Great Lakes as a result of weathering

1050 (Ahier \& Tracy, 1995). Nearly all of the steps of nuclear power generation have occurred in the

1051 Great Lakes basin in the forms of mining, fuel preparation, power production, and waste

1052 management (Ahier \& Tracy, 1995). In the Port Hope Area of Concern (north shore of Lake

1053 Ontario), water quality and environmental health were threatened by U contamination, a result of

1054 poor operation and waste management practices of Eldorado Mining and Refining between 1933

1055 and 1953 (Government of Canada, 2017). An estimated 85,000 - 95,000 cubic meters of

1056 sediment containing radioactive material is present in this harbor in Ontario on the north shore of

1057 Lake Ontario. Contaminated soils from Port Hope have U concentrations of up to 258 ppm. .

1058 Stable U concentrations have not been analyzed in sediment cores of the Great Lakes.

1059

1060 A Note on Oxides

1061 Several metals in aquatic systems are commonly present as detrital oxides. Fe and Mn oxides are

1062 particularly major sources of metals from river systems. Heavy metals are frequently sorbed to

1063 the surface of oxide molecules. Oxides may represent portions of an element that are not part of

1064 other rocks, i.e. the actual mineral formations or ores. Some notable oxides include hematite

$1065\left(\mathrm{Fe}_{2} \mathrm{O}_{3}\right)$, an economically important iron ore that is found around the southern and northwestern

1066 shores of Lake Superior in Michigan, Wisconsin, and Minnesota, as well as ilmenite $\left(\mathrm{Fe}_{2} \mathrm{TiO}_{3}\right)$,

1067 the major source of Ti (Klein \& Dutrow, 2008).

1068 Summary/Discussion

1069 Many studies have been devoted to analyzing inorganic geochemistry in the Great Lakes, and we

1070 have summarized metals as they relate to geochemistry and environmental stress in the lakes.

1071 Through these studies, natural conditions and anthropogenic impacts have been measured over

1072 time through the sourcing of metals from catchments, industry, agriculture, mining, and other

1073 human activities. Several studies also show reductions in these metals in the atmosphere, water, 
1074 and lake sediment after legislation and mitigation efforts. With a few exceptions, it is difficult to 1075 pinpoint sources of contaminant metals due to their ubiquity in minerals comprising the bedrock 1076 and soils in the Great Lakes catchment. This comprehensive summary of Great Lakes-relevant 1077 metals serves as a key reference for the companion manuscript that details the implications of 1078 this review. This summary was a natural first step in developing background information for a 1079 partner study on applied metals geochemistry throughout the Great Lakes (Aliff et al., 2020). 1080 The companion paper features an analysis of 11 sediment cores collected from all five Great 1081 Lakes. Taken together we believe that these two papers represent a thorough summary of the 1082 knowledge to date of geochemistry in sediment cores in the Great Lakes system.

\section{Works Cited}

1084

1085

1086

1087

1088

1089

1090

1091

1092

1093

1094

1095

1096

1097

1098

1099

1100

1101

1102

1103

1104

1105

1106

1107

1108

1109

1110

1111

1112

1113

1114

1115
Adamec J. B. \& Springer D. B. (1968). Nickel. In C. A. Hampel (Ed.), The Encyclopedia of the Chemical Elements (pp. 437-445). New York: Reinhold Book Corporation.

Agency for Toxic Substances and Disease Registry (ATSDR). (1990). Toxicological profile for thorium. Atlanta, GA: U.S. Department of Health and Human Services, Public Health Service.

Agency for Toxic Substances and Disease Registry (ASTDR). (2004a). Toxicological Profile for cesium. Atlanta, GA: U.S. Department of Health and Human Services, Public Health Service. Agency for Toxic Substances and Disease Registry (ASTDR). (2004b). Toxicological profile for cobalt. Atlanta, GA: U.S. Department of Health and Human Services, Public Health Service. Agency for Toxic Substances and Disease Registry (ASTDR). (2004c). Toxicological profile for copper. Atlanta, GA: U.S. Department of Health and Human Services, Public Health Service. Agency for Toxic Substances and Disease Registry (ASTDR). (2005a). Toxicological profile for nickel. Atlanta, GA: U.S. Department of Health and Human Services, Public Health Service.

Agency for Toxic Substances and Disease Registry (ASTDR). (2005b). Toxicological profile for zinc. Atlanta, GA: U.S. Department of Health and Human Services, Public Health Service.

Agency for Toxic Substances and Disease Registry (ATSDR). (2007a). Toxicological profile for arsenic. Atlanta, GA: U.S. Department of Health and Human Services, Public Health Service.

Agency for Toxic Substances and Disease Registry (ATSDR). (2007b). Toxicological profile for barium and barium compounds. Atlanta, GA: U.S. Department of Health and Human Services, Public Health Service.

Agency for Toxic Substances and Disease Registry (ATSDR). (2007c). Toxicological profile for lead. Atlanta, GA: U.S. Department of Health and Human Services, Public Health Service.

Agency for Toxic Substances and Disease Registry (ATSDR). (2008). Toxicological Profile for aluminum. Atlanta, GA: U.S. Department of Health and Human Services, Public Health Service.

Agency for Toxic Substances and Disease Registry (ATSDR). (2012a). Toxicological Profile for cadmium. Atlanta, GA: U.S. Department of Health and Human Services, Public Health Service.

Agency for Toxic Substances and Disease Registry (ATSDR). (2012b). Toxicological Profile for chromium. Atlanta, GA: U.S. Department of Health and Human Services, Public Health Service. 
1116 Agency for Toxic Substances and Disease Registry (ATSDR). (2012c). Toxicological Profile for

1117

1118

1119

1120

1121

1122

1123

1124

1125

1126

1127

1128

1129

1130

1131

1132

1133

1134

1135

1136

1137

1138

1139

1140

1141

1142

1143

1144

1145

1146

1147

1148

1149

1150

1151

1152

1153

1154

1155

1156

1157

1158

1159

1160

1161 vanadium. Atlanta, GA: U.S. Department of Health and Human Services, Public Health Service.

Agency for Toxic Substances and Disease Registry (ASTDR). (2016). Review of Analysis of Particulate Matter and Metal Exposures in Air: KCBX (aka, "Chicago Petroleum Coke" Sites) [Health Consultation]. Atlanta, GA: U.S. Department Of Health And Human Services. Agency for Toxic Substances and Disease Registry (ATSDR). (2017a). Toxicological profile for antimony. (Draft for Public Comment). Atlanta, GA: U.S. Department of Health and Human Services, Public Health Service.

Agency for Toxic Substances and Disease Registry (ATSDR). (2017b). Toxicological profile for silica. (Draft for Public Comment). Atlanta, GA: U.S. Department of Health and Human Services, Public Health Service.

Ahier, B. A., \& Tracy, B. L. (1995). Radionuclides in the Great Lakes basin. Environmental Health Perspectives, 103 (Suppl 9), 89.

Alderton, D. (1985). Sediments. In Historical Monitoring, MARC. Monitoring and Assessment Research Centre, Technical Report no. 31. University of London.

Aliff, M. N., Reavie, E. D., Post, S. P., \& Zanko, L. M. (2020). Anthropocene geochemistry of metals in sediment cores from the Laurentian Great Lakes. PeerJ, in press.

Alloway, B. J. (2013a). Molybdenum. In B. J. Alloway (Ed.), Heavy Metals in Soils: Trace Metals and Metalloids in Soils and their Bioavailability (Third Edition, pp. 527-534).

Alloway, B. J. (2013b). Tin. In B. J. Alloway (Ed.), Heavy Metals in Soils: Trace Metals and Metalloids in Soils and their Bioavailability (Third Edition, pp. 551-558).

Alloway, B. J. (2013c). Uranium. In B. J. Alloway (Ed.), Heavy Metals in Soils: Trace Metals and Metalloids in Soils and their Bioavailability (Third Edition, pp. 565-577).

Alsaffar, A. H. (2017). Trace Metals in Surface Sediments of St. Clair River and Lake St. Clair, Michigan. Retrieved from https://deepblue.lib.umich.edu/handle/2027.42/136198

Amiro, B. D. (1993). Protection of the environment from nuclear fuel waste radionuclides: a framework using environmental increments. Science of the Total Environment, 128(2-3), $157-189$.

Aral, H., \& Vecchio-Sadus, A. (2008). Toxicity of lithium to humans and the environment-A literature review. Ecotoxicology and Environmental Safety, 70(3), 349-356. https://doi.org/10.1016/j.ecoenv.2008.02.026

Arthur, J. W., Benoit, D. A., Olson, D. T., Mattson, V. R., \& Swain, W. R. (1973). Periphyton growth on artificial substrates in Lake Superior (Studies Regarding the Effect of The Reserve Mining Company Discharge on Lake Superior). U.S. Environmental Protection Agency.

Azcue, J. M., Rosa, F., \& Mudroch, A. (1996). Distribution of Major and Trace Elements in Sediments and Pore Water of Lake Erie. Journal of Great Lakes Research, 22(2), 389-402.

Bache, B. W. (1986). Aluminium mobilization in soils and waters. Journal of the Geological Society, 143(4), 699-706.

Baehr, M. M., \& McManus, J. (2003). The measurement of phosphorus and its spatial and temporal variability in the western arm of Lake Superior. Journal of Great Lakes Research, 29(3), 479-487.

Baker, D. B., Confesor, R., Ewing, D. E., Johnson, L. T., Kramer, J. W., \& Merryfield, B. J. (2014). Phosphorus loading to Lake Erie from the Maumee, Sandusky and Cuyahoga rivers: The importance of bioavailability. Journal of Great Lakes Research, 40(3), 502-517.

Peer) reviewing PDF | (2020:01:44690:1:0:NEW 22 Mar 2020) 
1162

1163

1164

1165

1166

1167

1168

1169

1170

1171

1172

1173

1174

1175

1176

1177

1178

1179

1180

1181

1182

1183

1184

1185

1186

1187

1188

1189

1190

1191

1192

1193

1194

1195

1196

1197

1198

1199

1200

1201

1202

1203

1204

1205

1206

1207

https://doi.org/10.1016/j.jglr.2014.05.001Barksdale, J. (1968). Titanium. In C. A. Hampel (Ed.), The Encyclopedia of the Chemical Elements (pp. 732-739). New York: Reinhold Book Corporation.

Bassler, R. (2016). EPA, BP reach agreement to resolve water and air violations at Whiting Refinery. News Releases from Region 05. Retrieved from https://archive.epa.gov/epa/newsreleases/epa-bp-reach-agreement-resolve-water-and-airviolations-whiting-refinery.html

Bau, M., Knappe, A., \& Dulski, P. (2006). Anthropogenic gadolinium as a micropollutant in river waters in Pennsylvania and in Lake Erie, northeastern United States. Chemie Der Erde Geochemistry, 66(2), 143-152. https://doi.org/10.1016/j.chemer.2006.01.002

Belzile, N., Chen, Y.-W., Gunn, J. M., \& Dixit, S. S. (2004). Sediment trace metal profiles in lakes of Killarney Park, Canada. Environmental Pollution, 130(2), 239-248. https://doi.org/10.1016/j.envpol.2003.12.003

Biegalski, S. R., \& Hopke, P. K. (2004). Total Potential Source Contribution Function Analysis of Trace Elements Determined in Aerosol Samples Collected near Lake Huron. Environmental Science \& Technology, 38(16), 4276-4284. https://doi.org/10.1021/es035196s

Blowes, D. W., Ptacek, C. J., Jambor, J. L., Weisener, C. G., Paktunc, D., Gould, W. D., \& Johnson, D. B. (2014). The Geochemistry of Acid Mine Drainage. In Treatise on Geochemistry (pp. 131-190). Elsevier. https://doi.org/10.1016/B978-0-08-095975-7.00905-0

Boës, X., Rydberg, J., Martinez-Cortizas, A., Bindler, R., \& Renberg, I. (2011). Evaluation of conservative lithogenic elements ( $\mathrm{Ti}, \mathrm{Zr}, \mathrm{Al}$, and $\mathrm{Rb}$ ) to study anthropogenic element enrichments in lake sediments. Journal of Paleolimnology, 46(1), 75-87. https://doi.org/10.1007/s10933-011-9515-z

Boyle, R. W., \& Jonasson, I. R. (1973). The geochemistry of arsenic and its use as an indicator element in geochemical prospecting. Journal of Geochemical Exploration, 2(3), 251-296. https://doi.org/10.1016/0375-6742(73)90003-4

Breteler, R. J., Bowen, V. T., Schneider, D. L., \& Henderson, R. (1984). Sedimentological reconstruction of the recent pattern of mercury pollution in the Niagara River. Environmental Science \& Technology, 18(6), 404-409.

Cahill, R. A. (1981). Geochemistry of Recent Lake Michigan Sediments (Circular No. 517). Champaign, Illinois: Illinois Institute of Natural Resources, State Geological Survey Division.

Callender, E. (1969). Geochemical characteristics of Lakes Michigan and Superior sediments. In Proceedings of the 12th Conference of Great Lakes Research (pp. 124-160).

Campbell, L. M., Fisk, A. T., Wang, X., Köck, G., \& Muir, D. C. (2005). Evidence for biomagnification of rubidium in freshwater and marine food webs. Canadian Journal of Fisheries and Aquatic Sciences, 62(5), 1161-1167. https://doi.org/10.1139/f05-027

Canada, \& United States of America (1972). Agreement between Canada and the United States of America on Great Lakes Water Quality.

Carilli, J., Williams, B., Schöne, B. R., Krause, R. A., \& Fallon, S. J. (2015). Historical Contaminant Records from Sclerochronological Archives. In Environmental Contaminants (pp. 355-391). Springer.

Chambers, L. G., Chin, Y.-P., Filippelli, G. M., Gardner, C. B., Herndon, E. M., Long, D. T., Lyons, W. B., Macpherson, G. L., McElmurry, S. P., McLean, C. E., Moore, J., Moyer, R. P., Neumann, K., Nezat, C. A., Soderberg, K., Teutsch, N., \& Widom, E. (2016). Developing the

Peer) reviewing PDF | (2020:01:44690:1:0:NEW 22 Mar 2020) 
1208 scientific framework for urban geochemistry. Applied Geochemistry, 67, 1-20. https://doi.org/10.1016/j.apgeochem.2016.01.005

1210

1211

1212

1213

1214

Chapra, S. C., Dove, A., \& Warren, G. J. (2012). Long-term trends of Great Lakes major ion chemistry. Journal of Great Lakes Research, 38(3), 550-560. https://doi.org/10.1016/j.jglr.2012.06.010

Chen, Y.-W., Deng, T.-L., Filella, M., \& Belzile, N. (2003). Distribution and Early Diagenesis of Antimony Species in Sediments and Porewaters of Freshwater Lakes. Environmental Science \& Technology, 37(6), 1163-1168. https://doi.org/10.1021/es025931k

Christensen, E. R., \& Chien, N.-K. (1981). Fluxes of arsenic, lead, zinc, and cadmium to Green Bay and Lake Michigan sediments. Environmental Science \& Technology, 15(5), 553-558.

Christensen, E. R., \& Osuna, J. L. (1989). Atmospheric fluxes of lead, zinc, and cadmium from frequency domain deconvolution of sedimentary records. Journal of Geophysical Research: Oceans, 94(C10), 14585-14597.

Clemente, R. (2013). Antimony. In B. J. Alloway (Ed.), Heavy Metals in Soils: Trace Metals and Metalloids in Soils and their Bioavailability (Third Edition, pp. 497-506). Dordrecht: Springer Netherlands.

Cole, K. L., Engstrom, D. R., Futyma, R. P., \& Stottlemyer, R. (1990). Past atmospheric deposition of metals in northern Indiana measured in a peat core from Cowles Bog. Environmental Science \& Technology, 24(4), 543-549.

Cronan, D. S., \& Thomas, R. L. (1972). Geochemistry of ferromanganese oxide concretions and associated deposits in Lake Ontario. Geological Society of America Bulletin, 83(5), 14931502.

Daane, A. H. (1968). Vanadium. In C. A. Hampel (Ed.), The Encyclopedia of the Chemical Elements (pp. 787-795). New York: Reinhold Book Corporation.

Dias, M. I., \& Prudêncio, M. I. (2008). On the importance of using scandium to normalize geochemical data preceding multivariate analyses applied to archaeometric pottery studies. Microchemical Journal, 88(2), 136-141. https://doi.org/10.1016/j.microc.2007.11.009

Dittrich, M., Moreau, L., Gordon, J., Quazi, S., Palermo, C., Fulthorpe, R., Katsev, S., Bollmann, J., \& Chesnyuk, A. (2015). Geomicrobiology of Iron Layers in the Sediment of Lake Superior. Aquatic Geochemistry, 21(2-4), 123-140. https://doi.org/10.1007/s10498-0159258-y

Dove, A. (2009). Long-term trends in major ions and nutrients in Lake Ontario. Aquatic Ecosystem Health \& Management, 12(3), 281-295. https://doi.org/10.1080/14634980903136388

Drevnick, P. E., Engstrom, D. R., Driscoll, C. T., Swain, E. B., Balogh, S. J., Kamman, N. C., ... Rossmann, R. (2012). Spatial and temporal patterns of mercury accumulation in lacustrine sediments across the Laurentian Great Lakes region. Environmental Pollution, 161, 252-260. https://doi.org/10.1016/j.envpol.2011.05.025

Driscoll, C. T. (1985). Aluminum in acidic surface waters: chemistry, transport, and effects. Environmental Health Perspectives, 63, 93.

Driscoll, C. T. (1989). The Chemistry of Aluminum in Surface Waters. In G. Sposito (Ed.), The Environmental chemistry of aluminum. Boca Raton, Fla: CRC Press.

Driscoll, C. T., \& Schecher, W. D. (1990). The chemistry of aluminum in the environment. Environmental Geochemistry and Health, 12(1-2), 28-49. 
1252 Durham, R. W., \& Joshi, S. R. (1984). Dose equivalent commitments from fallout radionuclides

1253

1254

1255

1256

1257

1258

1259

1260

1261

1262

1263

1264

1265

1266

1267

1268

1269

1270

1271

1272

1273

1274

1275

1276

1277

1278

1279

1280

1281

1282

1283

1284

1285

1286

1287

1288

1289

1290

1291

1292

1293

1294

1295

1296 in the open waters of the Great Lakes. 1973-1981. Environmental Monitoring and Assessment, 4(4), 405-417.

Edgington, D. N., \& Robbins, J. A. (1976). Records of Lead Deposition in Lake Michigan Sediments since 1800. Environmental Science \& Technology, 10(3).

Edgington, D. N., Robbins, J. A., \& Karttunen, J. O. (1974). The distribution of 210pb and stable lead in Lake Michigan sediments. In Argonne National Laboratory. Radiological and Environmental Research Division., Radiological and Environmental Research Division Annual Report (pp. 63-76).

Emsley, J. (2002). Nature's building blocks: an A-Z guide to the elements. Oxford University Press.

Emsley, J. (2014). Unsporting scandium. Nature Chemistry, 6(11), 1025-1025.

Eyring, L. (1968). Praseodymium. In C. A. Hampel (Ed.), The Encyclopedia of the Chemical Elements (pp. 561-567). New York: Reinhold Book Corporation.

Filella, M., Belzile, N., \& Chen, Y.-W. (2002). Antimony in the environment: A review focused on natural waters: I. Occurrence. Earth-Science Reviews, 57(1), 125-176.

Fitchko, J., \& Hutchinson, T. C. (1975). A comparative study of heavy metal concentrations in river mouth sediments around the great lakes. Journal of Great Lakes Research, 1(1), 46-78.

Fleet, A. (1984). Aqueous and sedimentary geochemistry of the rare earth elements. In Developments in Geochemistry: Vol. 2. Rare Earth Element Geochemistry (pp. 343-373). Elsevier.

Foote Mineral Co. (1968). Vanadium. In C. A. Hampel (Ed.), The Encyclopedia of the Chemical Elements (pp. 787-795). New York: Reinhold Book Corporation.

Förstner, U. (1976). Lake sediments as indicators of heavy-metal pollution. Naturwissenschaften, 63(10), 465-470.

Förstner, U., \& Wittmann, G. T. W. (1979). Metal Pollution in the Aquatic Environment. Berlin, Heidelberg: Springer Berlin Heidelberg. https://doi.org/10.1007/978-3-642-96511-1

Forsythe, K. W., \& Marvin, C. H. (2009). Assessing historical versus contemporary mercury and lead contamination in Lake Huron sediments. Aquatic Ecosystem Health \& Management, 12(1), 101-109. https://doi.org/10.1080/14634980802690873

Gerke, T. L., Little, B. J., Luxton, T. P., Scheckel, K. G., \& Maynard, J. B. (2013). Strontium Concentrations in Corrosion Products from Residential Drinking Water Distribution Systems. Environmental Science \& Technology, 47(10), 5171-5177. https://doi.org/10.1021/es4000609

Giussani, A. (2011). Molybdenum in the Environment and its Relevance for Animal and Human Health. In J. O. Nriagu (Ed.), Encyclopedia of Environmental Health (Vol. 3, pp. 840-846). Elsevier B.V.

Gobeil, C., Tessier, A., \& Couture, R.-M. (2013). Upper Mississippi Pb as a mid-1800s chronostratigraphic marker in sediments from seasonally anoxic lakes in Eastern Canada. Geochimica et Cosmochimica Acta, 113, 125-135. https://doi.org/10.1016/j.gca.2013.02.023

Goldberg, E. D., Hodge, V. F., Griffin, J. J., Koide, M., \& Edgington, D. N. (1981). Impact of fossil fuel combustion on the sediments of Lake Michigan. Environmental Science \& Technology, 15(4), 466-471.

Government of Canada. (2017, February 13). Port Hope Area of Concern. Retrieved April 12, 2017, from https://www.ec.gc.ca/raps-pas/default.asp?lang=En\&n=8BB3DAED-1

Peer) reviewing PDF | (2020:01:44690:1:0:NEW 22 Mar 2020) 
1297 Graney, J. R., Halliday, A. N., Keeler, G. J., Nriagu, J. O., Robbins, J. A., \& Norton, S. A.

1298

1299

1300

1301

1302

1303

1304

1305

1306

1307

1308

1309

1310

1311

1312

1313

1314

1315

1316

1317

1318

1319

1320

1321

1322

1323

1324

1325

1326

1327

1328

1329

1330

1331

1332

1333

1334

1335

1336

1337

1338

1339

1340

1341

1342

(1995). Isotopic record of lead pollution in lake sediments from the northeastern United States. Geochimica et Cosmochimica Acta, 59(9), 1715-1728.

Great Lakes Commission (2008). The Economics of Soil Erosion and Sedimentation in the Great Lakes Basin. Prepared for the U.S. Army Corps of Engineers Great Lakes \& Ohio River Division, $102 \mathrm{p}$.

Grinstead, R. R. (1968). Biogeochemical Behavior of Copper. In C. A. Hampel (Ed.), The Encyclopedia of the Chemical Elements (pp. 379-389). New York: Reinhold Book Corporation.

Gross, W. H. (1968). Magnesium. In C. A. Hampel (Ed.), The Encyclopedia of the Chemical Elements (pp. 379-389). New York: Reinhold Book Corporation.

Gschneidner, K. A. (1968). Cerium. In C. A. Hampel (Ed.), The Encyclopedia of the Chemical Elements (pp. 119-127). New York: Reinhold Book Corporation.

Gummow, B. (2011). Vanadium: Environmental Pollution and Health Effects. In J. O. Nriagu (Ed.), Encyclopedia of Environmental Health (Vol. 5, pp. 628-636). Elsevier B.V. Retrieved from https://core.ac.uk/download/pdf/11573998.pdf

Hampel, C. A. (1968a). Barium. In C. A. Hampel (Ed.), The Encyclopedia of the Chemical Elements (pp. 43-46). New York: Reinhold Book Corporation.

Hampel, C. A. (1968b). Hafnium. In C. A. Hampel (Ed.), The Encyclopedia of the Chemical Elements (pp. 251-256). New York: Reinhold Book Corporation.

Hampel, C. A. (1968c). Iron. In C. A. Hampel (Ed.), The Encyclopedia of the Chemical Elements (pp. 305-313). New York: Reinhold Book Corporation.

Hampel, C. A. (1968d). Manganese. In C. A. Hampel (Ed.), The Encyclopedia of the Chemical Elements (pp. 389-399). New York: Reinhold Book Corporation.

Hampel, C. A. (1968e). Strontium. In C. A. Hampel (Ed.), The Encyclopedia of the Chemical Elements (pp. 653-663). New York: Reinhold Book Corporation.

Hartig, J. H., \& Thomas, R. L. (1988). Development of plans to restore degraded areas in the Great Lakes. Environmental Management, 12(3), 327-347.

Heim, S., \& Schwarzbauer, J. (2012). Geochronology of Anthropogenic Contaminants in Aquatic Sediment Archives. In Environmental Chemistry for a Sustainable World (pp. 209257). Springer.

Herrmann, H., Nolde, J., Berger, S., \& Heise, S. (2016). Aquatic ecotoxicity of lanthanum - A review and an attempt to derive water and sediment quality criteria. Ecotoxicology and Environmental Safety, 124, 213-238. https://doi.org/10.1016/j.ecoenv.2015.09.033

Höllriegl, V., \& München, H. (2011). Strontium in the environment and possible human health effects. In J. O. Nriagu (Ed.), Encyclopedia of Environmental Health (Vol. 5, pp. 663-275). Elsevier B.V.

Holsen, T. M., Noll, K. E., Fang, G. C., Lee, W. J., Lin, J. M., \& Keeler, G. J. (1993). Dry deposition and particle size distributions measured during the Lake Michigan urban air toxics study. Environmental Science \& Technology, 27(7), 1327-1333.

Horovitz, C. T. (1975). Scandium: its occurrence, chemistry, physics, metallurgy, biology, and technology. Academic Press.

Hough, J. L. (1958). Geology of the Great lakes. University of Illinois Press.

Ikem, A., \& Adisa, S. (2011). Runoff effect on eutrophic lake water quality and heavy metal distribution in recent littoral sediment. Chemosphere, 82(2), 259-267. https://doi.org/10.1016/j.chemosphere.2010.09.048

Peer) reviewing PDF | (2020:01:44690:1:0:NEW 22 Mar 2020) 
1343 Ilton, E. S. (1999). Chromium. In C. P. Marshall \& R. W. Fairbridge (Eds.), Encyclopedia of

1344

1345

1346

1347

1348

1349

1350

1351

1352

1353

1354

1355

1356

1357

1358

1359

1360

1361

1362

1363

1364

1365

1366

1367

1368

1369

1370

1371

1372

1373

1374

1375

1376

1377

1378

1379

1380

1381

1382

1383

1384

1385

1386

1387 Geochemistry (pp. 81-82).

Jeong, J., \& McDowell, S. D. (2003). Characterization and transport of contaminated sediments in the southern central Lake Superior. Journal of Minerals and Materials Characterization and Engineering, 2(02), 111.

Keays, R. R., \& Lightfoot, P. C. (2015). Geochemical Stratigraphy of the Keweenawan Midcontinent Rift Volcanic Rocks. Economic Geology, 110, 1235-1267.

Kemp, A. L. W., Anderson, T. W., Thomas, R. L., \& Mudrochova, A. (1974). Sedimentation rates and recent sediment history of Lakes Ontario, Erie and Huron. Journal of Sedimentary Research, 44(1). Retrieved from http://archives.datapages.com/data/doi/10.1306/74D729C32B21-11D7-8648000102C1865D

Kemp, A., Gray, C., \& Mudrochova, A. (1972). Changes in C, N, P, and S in the last 140 years in three cores from Lakes Ontario, Erie, and Huron. In H. E. Allen \& J. R. Kramer (Eds.), Nutrients in Natural Waters.

Kemp, A. L. W., \& Thomas, R. L. (1976a). Impact of man's activities on the chemical composition in the sediments of Lakes Ontario, Erie and Huron. Water, Air, \& Soil Pollution, 5(4), 469-490.

Kemp, A. L., \& Thomas, R. L. (1976b). Sediment Geochemistry: Cultural Impact on the Geochemistry of the Sediments of Lakes Ontario, Erie and Huron. Geoscience Canada, 3(3). Retrieved from https://journals.lib.unb.ca/index.php/GC/article/view/1196

Kemp, A. L. W., Thomas, R. L., Dell, C. I., \& Jaquet, J.-M. (1976). Cultural Impact on the Geochemistry of Sediments in Lake Erie. Journal of the Fisheries Research Board of Canada, 33, 440-462.

Kemp, A. L., Williams, J. D., Thomas, R. L., \& Gregory, M. L. (1978). Impact of man's activities on the chemical composition of the sediments of Lakes Superior and Huron. Water, Air, \& Soil Pollution, 10(4), 381-402.

Kerfoot, W. C., Harting, S. L., Jeong, J., Robbins, J. A., \& Rossmann, R. (2004). Local, regional, and global implications of elemental mercury in metal (copper, silver, gold, and zinc) ores: Insights from Lake Superior sediments. Journal of Great Lakes Research, 30, 162-184.

Kerfoot, W. C., Harting, S., Rossmann, R., \& Robbins, J. A. (1999). Anthropogenic copper inventories and mercury profiles from Lake Superior: Evidence for mining impacts. Journal of Great Lakes Research, 25(4), 663-682.

Kerfoot, W. C., Lauster, G., \& Robbins, J. A. (1994). Paleolimnological study of copper mining around Lake Superior: Artificial varves from Portage Lake provide a high resolution record. Limnology and Oceanography, 39(3), 649-669.

Kerfoot, W. C., \& Nriagu, J. O. (1999). Copper mining, copper cycling and mercury in the Lake Superior ecosystem: An introduction. Journal of Great Lakes Research, 25(4), 594-598.

Kerfoot, W. C., \& Robbins, J. A. (1999). Nearshore regions of Lake Superior: Multi-element signatures of mining discharges and a test of $\mathrm{Pb}-210$ deposition under conditions of variable sediment mass flux. Journal of Great Lakes Research, 25(4), 697-720.

Kennedy, E. J., Ruch, R., \& Shimp, N. F. (1971). Distribution of mercury in unconsolidated sediments from southern Lake Michigan. Environmental Geology No. 044.

Kerfoot, W. C., Urban, N. R., McDonald, C. P., Rossmann, R., \& Zhang, H. (2016). Legacy mercury releases during copper mining near Lake Superior. Journal of Great Lakes Research, 42(1), 50-61. https://doi.org/10.1016/j.jglr.2015.10.007 
1388 Khan, S., Kazi, T. G., Arain, M. B., Kolachi, N. F., Baig, J. A., Afridi, H. I., \& Shah, A. Q.

1389

1390

1391

1392

1393

1394

1395

1396

1397

1398

1399

1400

1401

1402

1403

1404

1405

1406

1407

1408

1409

1410

1411

1412

1413

1414

1415

1416

1417

1418

1419

1420

1421

1422

1423

1424

1425

1426

1427

1428

1429

1430

1431

1432

1433 (2013). Evaluation of Bioavailability and Partitioning of Aluminum in Sediment Samples of Different Ecosystems by Modified Sequential Extraction Methods. CLEAN - Soil, Air, Water, 41(8), 808-815. https://doi.org/10.1002/clen.201000197

Klein, C., \& Dutrow, B. (2008). Crystal Chemistry and Systematic Descriptions of Oxides, Hydroxides, and Halides. In: The 23rd Edition of the Manual of Mineral Science (pp. 368398). John Wiley \& Sons, Inc., New York

Kolak, J. J., Long, D. T., Beals, T. M., Eisenrich, S. J., \& Swackhamer, D. L. (1998). Anthropogenic inventories and historical and present accumulation rates of copper in Great Lakes sediments. Applied Geochemistry, 13(1), 59-75.

Kolak, J. J., Long, D. T., Kerfoot, W. C., Beals, T. M., \& Eisenreich, S. J. (1999). Nearshore versus offshore copper loading in Lake Superior sediments: Implications for transport and cycling. Journal of Great Lakes Research, 25(4), 611-624.

Korda, R. J., Henzler, T. E., Helmke, P. A., Jimenez, M. M., Haskin, L. A., \& Larsen, E. M. (1977). Trace elements in samples of fish, sediment and taconite from Lake Superior. Journal of Great Lakes Research, 3(1-2), 148-154.

Kovacik, T. L. (1972). Distribution of mercury in western Lake Erie water and bottom sediments (Doctoral dissertation). Bowling Green State University.

Kulaksız, S., \& Bau, M. (2011a). Anthropogenic gadolinium as a microcontaminant in tap water used as drinking water in urban areas and megacities. Applied Geochemistry, 26(11), 18771885. https://doi.org/10.1016/j.apgeochem.2011.06.011

Kulaksiz, S., \& Bau, M. (2011b). Rare earth elements in the Rhine River, Germany: First case of anthropogenic lanthanum as a dissolved microcontaminant in the hydrosphere. Environment International, 37(5), 973-979. https://doi.org/10.1016/j.envint.2011.02.018

Kulaksiz, S., \& Bau, M. (2013). Anthropogenic dissolved and colloid/nanoparticle-bound samarium, lanthanum and gadolinium in the Rhine River and the impending destruction of the natural rare earth element distribution in rivers. Earth and Planetary Science Letters, 362, 43-50. https://doi.org/10.1016/j.eps1.2012.11.033

Kuzyk, Z. Z. A., Macdonald, R. W., \& Johannessen. (2015). Calculating Rates and Dates and Interpreting Contaminant Profiles in Biomixed Sediments. In J. M. Blais, M. R. Rosen, \& J. P. Smol (Eds.), Environmental Contaminants: Using Natural Archives to Track Sources and Long-Term Trends of Pollution (Vol. 18, pp. 61-88). Springer Science+Business Media.

LaBerge, G. L. (1994). Geology of the Lake Superior region. Tucson, Ariz.: Geoscience Press.

Langmuir, D., \& Herman, J. S. (1980). The mobility of thorium in natural waters at low temperatures. Geochimica et Cosmochimica Acta, 44(11), 1753-1766.

Lanning, F. C. (1968). Silicon. In C. A. Hampel (Ed.), The Encyclopedia of the Chemical Elements (pp. 634-647). New York: Reinhold Book Corporation.

Larson, G., \& Schaetzl, R. (2001). Origin and evolution of the Great Lakes. Journal of Great Lakes Research, 27(4), 518-546.

Leland, H., Shukla, S. S., \& Shimp, N. F. (1973). Factors affecting distribution of lead and other trace elements in sediments of southern Lake Michigan. In P. C. Singer (Ed.), Trace Metals and Metal-Organic Interactions in Natural Waters.

Limburg, K. E., Walther, B. D., Lu, Z., Jackman, G., Mohan, J., Walther, Y., Nissling, A., Weber, P. K., \& Schmitt, A. K. (2015). In search of the dead zone: Use of otoliths for tracking fish exposure to hypoxia. Journal of Marine Systems, 141, 167-178.

https://doi.org/10.1016/j.jmarsys.2014.02.014

Peer) reviewing PDF | (2020:01:44690:1:0:NEW 22 Mar 2020) 
1434 Lindsay, K. L. (1968). Sodium. In C. A. Hampel (Ed.), The Encyclopedia of the Chemical

1435

1436

1437

1438

1439

1440

1441

1442

1443

1444

1445

1446

1447

1448

1449

1450

1451

1452

1453

1454

1455

1456

1457

1458

1459

1460

1461

1462

1463

1464

1465

1466

1467

1468

1469

1470

1471

1472

1473

1474

1475

1476

1477

1478 Elements (pp. 653-663). New York: Reinhold Book Corporation.

Long, D. T., Parsons, M. J., Yansa, C. H., Yohn, S. S., McLean, C. E., \& Vannier, R. G. (2010). Assessing the response of watersheds to catastrophic (logging) and possible secular (global temperature change) perturbations using sediment-chemical chronologies. Applied Geochemistry, 25(1), 143-158. https://doi.org/10.1016/j.apgeochem.2009.11.003

Lum, K. R., \& Leslie, J. K. (1983). Dissolved and particulate metal chemistry of the central and eastern basins of Lake Erie. Science of the Total Environment, 30, 99-109.

Mackay, D. A. R., \& Simandl, G. J. (2014). Geology, market and supply chain of niobium and tantalum - a review. Mineralium Deposita, 49(8), 1025-1047.

https://doi.org/10.1007/s00126-014-0551-2

Marvin, C. H., Charlton, M. N., Stern, G. A., Braekevelt, E., Reiner, E. J., \& Painter, S. (2003). Spatial and temporal trends in sediment contamination in Lake Ontario. Journal of Great Lakes Research, 29(2), 317-331.

Marvin, C., Painter, S., Williams, D., Richardson, V., Rossmann, R., \& Van Hoof, P. (2004). Spatial and temporal trends in surface water and sediment contamination in the Laurentian Great Lakes. Environmental Pollution, 129(1), 131-144.

Mackereth, F. J. H. (1966). Some chemical observations on post-glacial lake sediments. Philosophical Transactions of the Royal Society of London B: Biological Sciences, 250(765), 165-213.

Madejón, P. (2013). Barium. In B. J. Alloway (Ed.), Heavy Metals in Soils: Trace Metals and Metalloids in Soils and their Bioavailability (Third Edition, pp. 507-514).

Manning, P. G., Lum, K. R., \& Birchall, T. (1983). Forms of iron, phosphorus and trace-metal ions in a layered sediment core from Lake Ontario. The Canadian Mineralogist, 21(1), 121128.

Mantell, C. L. (1968). Calcium. In C. A. Hampel (Ed.), The Encyclopedia of the Chemical Elements (pp. 94-103). New York: Reinhold Book Corporation.

Martin, K. R. (2013). Silicon: The Health Benefits of a Metalloid. In Sigel, A., Sigel, H., \& Sigel, R. K. O. (Eds.), Interrelations between Essential Metal Ions and Human Diseases (Vol. 13). Dordrecht: Springer Science+Business Media. https://doi.org/10.1007/978-94-007-7500$\underline{8}$

Mayer, T., \& Johnson, M. G. (1994). History of anthropogenic activities in Hamilton Harbour as determined from the sedimentary record. Environmental Pollution, 86(3), 341-347.

Mayfield, D. B., \& Fairbrother, A. (2015). Examination of rare earth element concentration patterns in freshwater fish tissues. Chemosphere, 120, 68-74.

https://doi.org/10.1016/j.chemosphere.2014.06.010

McClain, J. H. (1968). Zirconium. In C. A. Hampel (Ed.), The Encyclopedia of the Chemical Elements (pp. 830-839). New York: Reinhold Book Corporation.

McCown, D. L. (1979). Differential tracing of oily waste and the associated water mass by tagging with rare earths. Water Research, 13(11), 1065-1076.

McKee, J. D., Wilson, T. P., Long, D. T., \& Owen, R. M. (1989). Pore water profiles and early diagenesis of $\mathrm{Mn}, \mathrm{Cu}$, and $\mathrm{Pb}$ in sediments from large lakes. Journal of Great Lakes Research, 15(1), 68-83.

Meriano, M., Eyles, N., \& Howard, K. W. F. (2009). Hydrogeological impacts of road salt from Canada's busiest highway on a Lake Ontario watershed (Frenchman's Bay) and lagoon, City 
1479

1480

1481

1482

1483

1484

1485

1486

1487

1488

1489

1490

1491

1492

1493

1494

1495

1496

1497

1498

1499

1500

1501

1502

1503

1504

1505

1506

1507

1508

1509

1510

1511

1512

1513

1514

1515

1516

1517

1518

1519

1520

1521

1522

1523

1524

of Pickering. Journal of Contaminant Hydrology, 107(1-2), 66-81.

https://doi.org/10.1016/j.jconhyd.2009.04.002

Merschel, G., \& Bau, M. (2015). Rare earth elements in the aragonitic shell of freshwater mussel Corbicula fluminea and the bioavailability of anthropogenic lanthanum, samarium and gadolinium in river water. Science of The Total Environment, 533, 91-101. https://doi.org/10.1016/j.scitotenv.2015.06.042

Meyers, P. A. (2003). Applications of organic geochemistry to paleolimnological reconstructions: a summary of examples from the Laurentian Great Lakes. Organic Geochemistry, 34(2), 261-289.

Mittlefehldt, D. W. (1999a). Magnesium. In C. P. Marshall \& R. W. Fairbridge (Eds.), Encyclopedia of Geochemistry (pp. 379). Springer Science \& Business Media.

Mittlefehldt, D. W. (1999b). Sodium. In C. P. Marshall \& R. W. Fairbridge (Eds.), Encyclopedia of Geochemistry (pp. 577-578). Springer Science \& Business Media.

Moore, J. W. (1991). Barium. In Inorganic contaminants of surface water: research and monitoring priorities (pp. 43-49). Springer Science \& Business Media.

Morey, G.B. (1992). Chemical composition of the eastern Biwabik Iron-Formation (early Proterozoic), Mesabi Range, Minnesota. Economic Geology 87(6): 1649-1658.

Mosheim, E. M. (1968a). Cesium. In C. A. Hampel (Ed.), The Encyclopedia of the Chemical Elements (pp. 127-133). New York: Reinhold Book Corporation.

Mosheim, E. M. (1968b). Rubidium. In C. A. Hampel (Ed.), The Encyclopedia of the Chemical Elements (pp. 604-610). New York: Reinhold Book Corporation.

Mothersill, J. S. (1977). Selected element concentrations in the post-glacial sediments of Thunder Bay, Lake Superior: distribution and methods of analyses. Canadian Journal of Earth Sciences, 14, 1054-1061.

Mothersill, J. S., \& Fung, P. C. (1972). The Stratigraphy, Mineralogy, and Trace Element Concentrations of the Quaternary Sediments of the Northern Lake Superior Basin. Canadian Journal of Earth Sciences, 9.

Mudhoo, A., Garg, V. K., \& Wang, S. (2012). Heavy Metals: Toxicity and Removal by Biosorption. In E. Lichtfouse, J. Schwarzbauer, \& D. Robert (Eds.), Environmental Chemistry for a Sustainable World (Vol. 2: Remediation of Air and Water Pollution, pp. 379-442). Springer.

Mudroch, A. (1985). Geochemistry of the Detroit River sediments. Journal of Great Lakes Research, 11(3), 193-200.

Mudroch, A. (1993). Lake Ontario sediments in monitoring pollution. Environmental Monitoring and Assessment, 28(2), 117-129.

Nádaská, G., Lesny, J., \& Michalik, I. (2012). Environmental Aspect of Manganese Chemistry. Hungarian Journal of Sciences, 1-16.

Nagajyoti, P. C., Lee, K. D., \& Sreekanth, T. V. M. (2010). Heavy metals, occurrence and toxicity for plants: a review. Environmental Chemistry Letters, 8(3), 199-216. https://doi.org/10.1007/s10311-010-0297-8

National Research Council (US) (1977). Committee on Medical and Biological Effects of Environmental Pollutants. Arsenic: Medical and Biologic Effects of Environmental Pollutants. Washington (DC): National Academies Press (US). Available from: https://www.ncbi.nlm.nih.gov/books/NBK231018/ doi: 10.17226/9003

Neustadter, H. E., Fordyce, J. S., \& King, R. B. (1976). Elemental Composition of Airborne Particulates And Source Identification: Data Analysis Techniques. Journal of the Air 
1525

1526

1527

1528

1529

1530

1531

1532

1533

1534

1535

1536

1537

1538

1539

1540

1541

1542

1543

1544

1545

1546

1547

1548

1549

1550

1551

1552

1553

1554

1555

1556

1557

1558

1559

1560

1561

1562

1563

1564

1565

1566

1567

1568

1569

1570

Pollution Control Association, 26(11), 1079-1084.

https://doi.org/10.1080/00022470.1976.10470364

North, R.L., Guildford, S.J., Smith, R.E.H., Havens, S.M. and Twiss, M.R. (2007). Evidence for phosphorus, nitrogen, and iron colimitation of phytoplankton communities in Lake Erie. Limnology and Oceanography, 52(1), pp.315-328.

Norton, S. A., Bienert Jr., R. W. Binford, M. W., \& Kahl, J. S. (1992). Stratigraphy of total metals in PIRLA sediment cores. Journal of Paleolimnology, 7(3), 191-214.

Norton, S. A., Wilson, T., Handley, M., \& Osterberg, E. C. (2007). Atmospheric deposition of cadmium in the northeastern USA. Applied Geochemistry, 22(6), 1217-1222.

https://doi.org/10.1016/j.apgeochem.2007.03.014

Nriagu, J. O. (1978). Dissolved silica in pore waters of Lakes Ontario, Erie, and Superior sediments. Limnology and Oceanography, 23(1), 53-67.

Nriagu, J. O. (1983). Arsenic enrichment in lakes near the smelters at Sudbury, Ontario. Geochimica et Cosmochimica Acta, 47(8), 1523-1526.

Nriagu, J. O., Kemp, A. L. W., Wong, H. K. T., \& Harper, N. (1979). Sedimentary record of heavy metal pollution in Lake Erie. Geochimica et Cosmochimica Acta, 43(2), 247-258.

Nriagu, J. O., Wong, H. K., \& Snodgrass, W. J. (1983). Historical records of metal pollution in sediments of Toronto and Hamilton Harbours. Journal of Great Lakes Research, 9(3), 365373.

Nussmann, D. G. (1965). Trace elements in the sediments of Lake Superior (Ph.D. dissertation). The University of Michigan.

Ojakangas, R. W., Morey, G. B., and Green, J. C. (2001). The mesoproterozoic midcontinent rift system, Lake Superior region, USA. Sedimentary Geology 141-142, 421-442.

Olivarez, A. M., Owen, R. M., \& Long, D. T. (1989). Geochemistry of rare earth elements in benthic layer particulate matter and sediments of Lake Superior. Journal of Great Lakes Research, 15(1), 59-67.

Onishi, H. (1969). Arsenic. In K. H. Wedepohl (Ed.), Handbook of Geochemistry. Berlin: Springer-Verlag.

Ontario Ministry of Energy, Northern Development and Mines. (2019). GeologyOntario. Retrieved November 8, 2019, from http://www.geologyontario.mndm.gov.on.ca/index.html

Ouyang, D., \& Bartholic, J. (2003). Soil erosion and sediment assessment in the Great Lakes Basin. Michigan State University, Institute of Water Research.

Oxberry, J. R., Doudoroff, P., \& Anderson, D. W. (1978). Potential toxicity of taconite tailings to aquatic life in Lake Superior. Journal (Water Pollution Control Federation), 240-251.

Painter, S., Marvin, C., Rosa, F., Reynoldson, T. B., Charlton, M. N., Fox, M., ... Estenik, J. F. (2001). Sediment contamination in Lake Erie: A 25-year retrospective analysis. Journal of Great Lakes Research, 27(4), 434-448.

Peirson, D. H., Cawse, P. A., \& Cambray, R. S. (1974). Chemical uniformity of airborne particulate material, and a maritime effect. Nature, 251, 675-679.

Peretti, E. A. (1968). Copper. In C. A. Hampel (Ed.), The Encyclopedia of the Chemical Elements (pp. 653-663). New York: Reinhold Book Corporation.

Petersen, R. R. (1975). A paleolimnological study of the eutrophication of Lake Erie. Verhandlungen Des Internationalen Verein Limnologie, 19, 2274-2283.

Pirrone, N., Allegrini, I., Keeler, G. J., Nriagu, J. O., Rossmann, R., \& Robbins, J. A. (1998). Historical atmospheric mercury emissions and depositions in North America compared to mercury accumulations in sedimentary records. Atmospheric Environment, 32(5), 929-940.

Peer) reviewing PDF | (2020:01:44690:1:0:NEW 22 Mar 2020) 
1571 Plant, J., Bone, J., Voulvoulis, N., Kinniburgh, D., Smedley, P., Fordyce, F., \& Klinck, B.

1572

1573

1574

1575

1576

1577

1578

1579

1580

1581

1582

1583

1584

1585

1586

1587

1588

1589

1590

1591

1592

1593

1594

1595

1596

1597

1598

1599

1600

1601

1602

1603

1604

1605

1606

1607

1608

1609

1610

1611

1612

1613

1614

1615

1616 (2014). Arsenic and Selenium. In Treatise on Geochemistry (pp. 13-57). Elsevier. https://doi.org/10.1016/B978-0-08-095975-7.00902-5

Pompeani, D. P., Abbott, M. B., Bain, D. J., DePasqual, S., \& Finkenbinder, M. S. (2015). Copper mining on Isle Royale 6500-5400 years ago identified using sediment geochemistry from McCargoe Cove, Lake Superior. The Holocene, 25(2), 253-262. https://doi.org/10.1177/0959683614557574

Pompeani, D. P., Abbott, M. B., Steinman, B. A., \& Bain, D. J. (2013). Lake sediments record prehistoric lead pollution related to early copper production in North America. Environmental Science \& Technology, 47(11), 5545-5552.

Powell, J. E. (1968). Dysprosium. In C. A. Hampel (Ed.), Encyclopedia of the chemical elements (pp. 178-182). Reinhold Book Corporation.

Reavie, E. D., Cai, M., Twiss, M. R., Carrick, H. J., Davis, T. W., Johengen, T. H., Gossiaux, D., Smith, D. E., Palladino, D., Burtner, A. and Sgro, G. V. (2016). Winter-spring diatom production in Lake Erie is an important driver of summer hypoxia. Journal of Great Lakes Research, 42(3), pp.608-618.

Reavie, E. D., Heathcote, A. J. and Chraibi, V. L. S. (2014). Laurentian Great Lakes phytoplankton and their water quality characteristics, including a diatom-based model for paleoreconstruction of phosphorus. PloS ONE, 9(8), p.e104705.

Reavie, E. D., Robbins, J. A., Stoermer, E. F., Douglas, M. S., Emmert, G. E., Morehead, N. R., \& Mudroch, A. (2005). Paleolimnology of a fluvial lake downstream of Lake Superior and the industrialized region of Sault Saint Marie. Canadian Journal of Fisheries and Aquatic Sciences, 62(11), 2586-2608. https://doi.org/10.1139/f05-170

Reavie, E. D., Sgro, G. V., Estepp, L. R., Bramburger, A. J., Shaw Chraïbi, V. L., Pillsbury, R. W., Cai, M., Stow, C. A., \& Dove, A. (2017). Climate warming and changes in Cyclotella sensu lato in the Laurentian Great Lakes: Great Lakes warming and Cyclotella. Limnology and Oceanography, 62(2), 768-783. https://doi.org/10.1002/lno.10459

Reid, R. J., Rengel, Z., \& Smith, F. A. (1996). Membrane fluxes and comparative toxicities of aluminium, scandium and gallium. Journal of Experimental Botany, 47(12), 1881-1888.

Risch, M. R., Gay, D. A., Fowler, K. K., Keeler, G. J., Backus, S. M., Blanchard, P., Barres, J. A., \& Dvonch, J. T. (2012). Spatial patterns and temporal trends in mercury concentrations, precipitation depths, and mercury wet deposition in the North American Great Lakes region, 2002-2008. Environmental Pollution, 161, 261-271. https://doi.org/10.1016/j.envpol.2011.05.030

Ritson, P. I., Esser, B. K., Niemeyer, S., \& Flegal, A. R. (1994). Lead isotopic determination of historical sources of lead to Lake Erie, North America. Geochimica et Cosmochimica Acta, 58(15), 3297-3305.

Robbins, J. A. (1980). Sediments of southern Lake Huron: Elemental composition and accumulation rates. Retrieved from http://udspace.udel.edu/handle/19716/1427

Robbins, J. A., \& Callender, E. (1975). Diagenesis of manganese in Lake Michigan sediments. American Journal of Science, 275(5), 512-533.

Robbins, J., \& Edgington, D. (1974). Stable lead geochronology of fine-grained sediments in southern Lake Michigan (pp. 32-39). Argonne National Laboratory (ANL).

Robbins, J. A., \& Edgington, D. N. (1976). The distribution of selected chemical elements in the sediments of southern Lake Michigan. Radiological and Environmental Research Division Annual Report. 
1617 Robbins, J., Edgington, D., \& Parker, J. (1974). Distribution of amorphous, diatom frustule, and

1618

1619

1620

1621

1622

1623

1624

1625

1626

1627

1628

1629

1630

1631

1632

1633

1634

1635

1636

1637

1638

1639

1640

1641

1642

1643

1644

1645

1646

1647

1648

1649

1650

1651

1652

1653

1654

1655

1656

1657

1658

1659

1660

1661 dissolved silica in a lead-210 dated core from southern Lake Michigan. Argonne National Lab., Ill.(USA).

Rolfhus, K. R., Sakamoto, H. E., Cleckner, L. B., Stoor, R. W., Babiarz, C. L., Back, R. C., ... Hurley, J. P. (2003). Distribution and Fluxes of Total and Methylmercury in Lake Superior. Environmental Science \& Technology, 37(5), 865-872. https://doi.org/10.1021/es026065e

Rossmann, R. (1995). Trace element concentrations in 1988 Saginaw Bay sediments: comparison with historical data. The Lake Huron Ecosystem: Ecology, Fisheries and the Management. Ecovision World Monograph Series. Edited by M. Munawar, T. Edsall, and J. Leach. SPB Academic Publishing, Amsterdam, 343-364.

Rossmann, R. (2010). Protocol to Reconstruct Historical Contaminant Loading to Large Lakes: The Lake Michigan Sediment Record of Mercury. Environmental Science \& Technology, 44(3), 935-940. https://doi.org/10.1021/es902307c

Rossmann, R., \& Barres, J. (1988). Trace element concentrations in near-surface waters of the Great Lakes and methods of collection, storage, and analysis. Journal of Great Lakes Research, 14(2), 188-204.

Rossmann, R., Pfeiffer, E. L., \& Filkins, J. C. (2014). Lake Michigan sediment lead storage and history of loads. Journal of Great Lakes Research, 40(4), 851-858. https://doi.org/10.1016/j.jglr.2014.08.008

Ruch, R., Kennedy, E. J., \& Shimp, N. F. (1970). Distribution of arsenic in unconsolidated sediments from southern Lake Michigan. Environmental Geology No. 037.

Sakaguchi, A., Yamamoto, M., Sasaki, K., \& Kashiwaya, K. (2006). Uranium and Thorium Isotope Distribution in an Offshore Bottom Sediment Core of the Selenga Delta, Lake Baikal, Siberia. Journal of Paleolimnology, 35(4), 807-818. https://doi.org/10.1007/s10933005-5621-0

Sánchez-González, C., López-Chaves, C., Rivas-García, L., Galindo, P., Gómez-Aracena, J., Aranda, P., \& Llopis, J. (2013). Accumulation of Scandium in Plasma in Patients with Chronic Renal Failure.

Schaetzl, R. J., Mikesell, L. R., \& Velbel, M. A. (2006). Soil Characteristics Related to Weathering and Pedogenesis across a Geomorphic Surface of Uniform Age in Michigan. Physical Geography, 27(2), 170-188.

Schelske, C. L. (1988). Historic trends in Lake Michigan silica concentrations. International Review of Hydrobiology, 73(5), 559-591.

Schelske, C. L. (1991). Historical nutrient enrichment of Lake Ontario: paleolimnological evidence. Canadian Journal of Fisheries and Aquatic Sciences, 48(8), 1529-1538.

Schelske, C. L., Robbins, J. A., Gardner, W. S., Conley, D. J., \& Bourbonniere, R. A. (1988). Sediment record of biogeochemical responses to anthropogenic perturbations of nutrient cycles in Lake Ontario. Canadian Journal of Fisheries and Aquatic Sciences, 45(7), 12911303.

Schelske, C. L., Conley, D. J., Stoermer, E. F., Newberry, T. L., \& Campbell, C. D. (1987). Biogenic silica and phosphorus accumulation in sediments as indices of eutrophication in the Laurentian Great Lakes. In Paleolimnology IV (pp. 79-86). Springer.

Schelske, C. L., Conley, D. J., \& Warwick, W. F. (1985). Historical relationships between phosphorus loading and biogenic silica accumulation in Bay of Quinte sediments. Canadian Journal of Fisheries and Aquatic Sciences, 42(8), 1401-1409.

Peer] reviewing PDF | (2020:01:44690:1:0:NEW 22 Mar 2020) 
1662 Schelske, C. L., Stoermer, E. F., \& Kenney, W. F. (2006). Historic low-level phosphorus

1663

1664

1665

1666

1667

1668

1669

1670

1671

1672

1673

1674

1675

1676

1677

1678

1679

1680

1681

1682

1683

1684

1685

1686

1687

1688

1689

1690

1691

1692

1693

1694

1695

1696

1697

1698

1699

1700

1701

1702

1703

1704

1705 enrichment in the Great Lakes inferred from biogenic silica accumulation in sediments. Limnology and Oceanography, 51(1, part 2), 728-748.

Schleicher, J. A., \& Kuhn, J. K. (1970). Phosphorus content in unconsolidated sediments from southern Lake Michigan. Environmental Geology No. 039.

Schmidt, F. F. (1968). Niobium. In C. A. Hampel (Ed.), The Encyclopedia of the Chemical Elements (pp. 445-454). New York: Reinhold Book Corporation.

Schoeld, E. A. (1968). Potassium. In C. A. Hampel (Ed.), The Encyclopedia of the Chemical Elements (pp. 552-561). New York: Reinhold Book Corporation.

Schroeder, H. A., Nason, A. P., \& Tipton, I. H. (1969). Essential metals in man: magnesium. Journal of Chronic Diseases, 21(11-12), 815-841.

Seaborg, G. T. (1968). Uranium. In C. A. Hampel (Ed.), The Encyclopedia of the Chemical Elements (pp. 773-786). New York: Reinhold Book Corporation.

Selig, U., Leipe, T., \& Dörfler, W. (2007). Paleolimnological Records of Nutrient and Metal Profiles in Prehistoric, Historic and Modern Sediments of Three Lakes in North-eastern Germany. Water, Air, and Soil Pollution, 184(1-4), 183-194. https://doi.org/10.1007/s11270007-9407-Z

Sgro, G. V., \& Reavie, E. D. (2017). Lake Erie's ecological history reconstructed from the sedimentary record. Journal of Great Lakes Research 44(1), 54-69. https://doi.org/10.1016/j.jglr.2017.11.002

Sgro, G. V., \& Reavie, E. D. (2018). Fossil diatoms, geochemistry, and the Anthropocene paleolimnology of Lake Huron. Journal of Great Lakes Research, 44(4), 765-778. https://doi.org/10.1016/j.jglr.2018.05.015

Shahin, U., Yi, S.-M., Paode, R. D., \& Holsen, T. M. (2000). Long-Term Elemental Dry Deposition Fluxes Measured around Lake Michigan with an Automated Dry Deposition Sampler. Environmental Science \& Technology, 34(10), 1887-1892. https://doi.org/10.1021/es9907562

Shahzad, B., Tanveer, M., Hassan, W., Shah, A. N., Anjum, S. A., Cheema, S. A., \& Ali, I. (2016). Lithium toxicity in plants: Reasons, mechanisms and remediation possibilities - A review. Plant Physiology and Biochemistry, 107, 104-115. https://doi.org/10.1016/j.plaphy.2016.05.034

Shaw Chraïbi, V. L., Kireta, A. R., Reavie, E. D., Cai, M., \& Brown, T. N. (2014). A paleolimnological assessment of human impacts on Lake Superior. Journal of Great Lakes Research, 40(4), 886-897. https://doi.org/10.1016/j.jglr.2014.09.016

Sherman, L. S., Blum, J. D., Dvonch, J. T., Gratz, L. E., \& Landis, M. S. (2015). The use of Pb, $\mathrm{Sr}$, and $\mathrm{Hg}$ isotopes in Great Lakes precipitation as a tool for pollution source attribution. Science of the Total Environment, 502, 362-374. https://doi.org/10.1016/j.scitotenv.2014.09.034

Shimp, N. F., Leland, H. V., \& White, W. A. (1970). Distribution of major, minor, and trace constituents in unconsolidated sediments from southern Lake Michigan. Environmental Geology No. 032. Retrieved from https://www.ideals.illinois.edu/handle/2142/78835

Shimp, N. F., Schleicher, J. A., Ruch, R. R., Heck, D. B., \& Leland, H. V. (1971). Trace element and organic carbon accumulation in the most recent sediments of southern Lake Michigan. Environmental Geology No. 041. 
1706 Sigel, A., Sigel, H., \& Sigel, R. K. O. (Eds.). (2013). Interrelations between Essential Metal Ions

1707

1708

1709

1710

1711

1712

1713

1714

1715

1716

1717

1718

1719

1720

1721

1722

1723

1724

1725

1726

1727

1728

1729

1730

1731

1732

1733

1734

1735

1736

1737

1738

1739

1740

1741

1742

1743

1744

1745

1746

1747

1748

1749

1750

1751 and Human Diseases (Vol. 13). Dordrecht: Springer Science+Business Media. https://doi.org/10.1007/978-94-007-7500-8

Simmons, E. C. (1999). Rubidium. In C. P. Marshall \& R. W. Fairbridge (Eds.), Encyclopedia of Geochemistry (pp. 555-556). Springer Science \& Business Media.

Sly, P. G. (1991). The effects of land use and cultural development on the Lake Ontario ecosystem since 1750. Hydrobiologia, 213(1), 1-75.

Sly, P. G., \& Thomas, R. L. (1974). Review of Geological Research as it Relates to an Understanding of Great Lakes Limnology. Journal of the Fisheries Research Board of Canada, 31, 795-825.

Smolders, E. S. \& Mertens, J. (2013). Cadmium. In B. J. Alloway (Ed.), Heavy Metals in Soils: Trace Metals and Metalloids in Soils and their Bioavailability (Third Edition, pp. 283-311).

Smith I. C. \& Carson B. L. (1981) Trace metals in the environment. Ann Arbor, MI: Ann Arbor Science Publishers.

Smith, K. S. (1999). Barium. In C. P. Marshall \& R. W. Fairbridge (Eds.), Encyclopedia of Geochemistry (pp. 28-29). Springer Science \& Business Media.

Spengler, J., Lwebuga-Mukasa, J., Vallarino, J., Melly, S., Chillrud, S., Baker, J., \& Minegishi, T. (2011). Air Toxics Exposure from Vehicle Emissions at a U.S. Border Crossing: Buffalo Peace Bridge Study (Research Report No. 158). Boston, Massachusetts: Health Effects Institute. Retrieved from https://www.researchgate.net/profile/Judith_Chow/publication/51161783 Concentrations_of air toxics in motor vehicledominated environments/links/00b7d522de681c6d38000000.pdf

Sridharan, N., \& Lee, G. F. (1974). Phosphorus studies in lower Green Bay, Lake Michigan. Journal (Water Pollution Control Federation), 684-696.

Steinnes, E. S. (2013). Mercury. In B. J. Alloway (Ed.), Heavy Metals in Soils: Trace Metals and Metalloids in Soils and their Bioavailability (Third Edition, pp. 411-428).

Sutherland, R. A. (2000). Bed sediment-associated trace metals in an urban stream, Oahu, Hawaii. Environmental Geology, 39(6), 611-627.

Sweet, C. W., Weiss, A., \& Vermette, S. J. (1998). Atmospheric deposition of trace metals at three sites near the Great Lakes. Water, Air, \& Soil Pollution, 103(1), 423-439.

Taylor, S. R. (1964). Abundance of chemical elements in the continental crust: A new table. Geochimica et Cosmochimica Acta, 28(8), 1273-1285.

Tchounwou, P. B., Yedjou, C. G., Patlolla, A. K., \& Sutton, D. J. (2012). Heavy Metal Toxicity and the Environment. In A. Luch (Ed.), Molecular, Clinical and Environmental Toxicology (Vol. 101, pp. 133-164). Basel: Springer Basel. https://doi.org/10.1007/978-3-7643-8340$\underline{46}$

Thomas, R. L. (1972). The Distribution of Mercury in the Sediments of Lake Ontario. Canadian Journal of Earth Sciences, 9(6): 636-651.

Thompson, G. L. (1968). Europium. In C. A. Hampel (Ed.), The Encyclopedia of the Chemical Elements (pp. 207-212). New York: Reinhold Book Corporation.

Tkatcheva, V., Poirier, D., Chong-Kit, R., Furdui, V. I., Burr, C., Leger, R., Parmar, J., Switzer, T., Maedler, S., Reiner, E. J., Sherry, J. P., \& Simmons, D. B. D. (2015). Lithium an emerging contaminant: Bioavailability, effects on protein expression, and homeostasis disruption in short-term exposure of rainbow trout. Aquatic Toxicology, 161, 85-93. https://doi.org/10.1016/j.aquatox.2015.01.030 
1752 Torrey, M. S. (1976). Environmental status of the Lake Michigan region. volume 3. Chemistry of

1753

1754

1755

1756

1757

1758

1759

1760

1761

1762

1763

1764

1765

1766

1767

1768

1769

1770

1771

1772

1773

1774

1775

1776

1777

1778

1779

1780

1781

1782

1783

1784

1785

1786

1787

1788

1789

1790

1791

1792

1793

1794

1795

Lake Michigan. Argonne National Lab., Ill.(USA). Retrieved from https://www.osti.gov/scitech/biblio/7330301

Tourtelot, H.A. (1971). Chemical Compositions of Rock Types as Factors in Our Environment. In Cannon, H.L. and Hobbs, H.C. (Eds.), Environmental Geochemistry in Health and Disease, Geological Society of America Memoir 123, 13-29.

Tracy, B. L., \& Prantl, F. A. (1983). 25 years of fission product input to Lakes Superior and Huron. Water, Air, \& Soil Pollution, 19(1), 15-27.

United States of America. Federal Water Pollution Control Act Amendments of 1972. , Pub. L. No. 92-500 (1972).

U.S. Department of the Interior (USDOI), \& U.S. Geological Survey (USGS). (2017). Mineral Commodity Summaries 2017.

U.S. Geological Survey. (2018). The National Geologic Map Database. Retrieved from https://www.usgs.gov/products/maps/geologic-maps

Uren, N. C. (2013). Cobalt and Manganese. In B. J. Alloway (Ed.), Heavy Metals in Soils: Trace Metals and Metalloids in Soils and their Bioavailability (Third Edition, pp. 335-366).

Venkataraman, B., \& Sudha, S. (2005). Vanadium toxicity. Asian Journal of Experimental Sciences, 19(2), 127-134.

Verschoor, M. J., Powe, C. R., McQuay, E., Schiff, S. L., Venkiteswaran, J. J., Li, J., \& Molot, L. A. (2017). Internal iron loading and warm temperatures are pre-conditions for cyanobacterial dominance in embayments along Georgian Bay, Great Lakes. Canadian Journal of Fisheries and Aquatic Sciences. 74(9), 1439-1453.

Walters, L., Herdendorf, C. E., Charlesworth, L., Anders, H. K., Jackson, W. B., Skoch, E. J., Webb, D. K., Kovacik, T. L., \& Sikes, C. S. (1972). Mercury contamination and its relation to other physico-chemical parameters in the western basin of Lake Erie. Proceedings of the Fifteenth Conference on Great Lakes Research.

Walters Jr, L. J., Kovacik, T. L., \& Herdendorf, C. E. (1974). Mercury occurrence in sediment cores from western Lake Erie. Retrieved from https://kb.osu.edu/dspace/bitstream/handle/1811/22194/V074N1_001.pdf

Walters, L. J., \& Wolery, T. J. (1974). Transfer of heavy metal pollutants from Lake Erie bottom sediments to the overlying water. Ohio State Univ., Water Resources Center. Retrieved from http://ohioseagrant.osu.edu/archive/ documents/publications/CTR/CTR319\%20Transfer $\% 20$ of $\% 20$ Heavy $\% 20$ Metal $\% 20$ Pollution $\% 20$ from $\% 20$ Lake $\% 20$ Erie $\% 20$ bo ttom $\% 20$ sediments $\% 20$ to $\% 20$ the $\% 20$ overlaying $\% 20$ water.pdf

Walters, L., Wolery, T. J., \& Myser, R. D. (1974). Occurrence of As, Cd, Co, Cr, Cu, Fe, Hg, Ni, $\mathrm{Sb}$, and $\mathrm{Zn}$ in Lake Erie sediments. Presented at the In: Proceedings, Seventeenth Conference on Great Lakes Research, Part 1.

Warwick, W. F. (1978). Man and the Bay of Quinte, Lake Ontario: 2800 years of cultural influence, with special reference to the Chironomidae (Diptera), sedimentation and eutrophication. University of Manitoba.

Wehrmann, R. F. (1968). Tantalum. In C. A. Hampel (Ed.), The Encyclopedia of the Chemical Elements (pp. 681-689). New York: Reinhold Book Corporation.

Whaley, T. P. \& Currier, J. W. (1968). Phosphorus. In C. A. Hampel (Ed.), The Encyclopedia of the Chemical Elements (pp. 524-533). New York: Reinhold Book Corporation.

Peer) reviewing PDF | (2020:01:44690:1:0:NEW 22 Mar 2020) 
1796

1797

1798

1799

1800

1801

1802

1803

1804

1805

1806

1807

1808

1809

1810

1811

1812

1813

1814

1815

1816

1817

1818

1819

1820

1821

1822

1823

1824

1825
Williams, J. D. H., \& Mayer, T. (1972). Effects of sediment diagenesis and regeneration of phosphorus with special reference to Lakes Erie and Ontario. In H. E. Allen \& J. R. Kramer (Eds.), Nutrients in Natural Waters (pp. 281-315). John Wiley \& Sons, Inc.

Williams, J., Murphy, T., \& Mayer, T. (1976). Rates of accumulation of phosphorus forms in Lake Erie sediments. Journal of the Fisheries Board of Canada, 33(3), 430-439.

Williamson, M. A. (1999a). Copper. In C. P. Marshall \& R. W. Fairbridge (Eds.), Encyclopedia of Geochemistry (pp. 101-102). Springer Science \& Business Media.

Williamson, M. A. (1999b). Iron. In C. P. Marshall \& R. W. Fairbridge (Eds.), Encyclopedia of Geochemistry (pp. 348-353). Springer Science \& Business Media.

Winchester, J. W. (1972). A chemical model for Lake Michigan pollution: considerations on atmospheric and surface water trace metal inputs. Nutrients in Natural Waters, 317-332.

Wisconsin Geological and Natural History Survey 2019. Ilmenite. https://wgnhs.wisc.edu/minerals/ilmenite/ (accessed 12 August 2019).

Wolery, T. J., \& Walters Jr, L. (1974). Pollutant mercury and sedimentation in the western basin of Lake Erie. Proceedings of the Seventeeth Conference on Great Lakes Research.

Woolrich, P. F. (1973). Occurence of Trace Metals in the Environment An Overview. American Industrial Hygiene Association Journal, 34(5), 217-226. https://doi.org/10.1080/0002889738506837

Yin, R., Lepak, R. F., Krabbenhoft, D. P., \& Hurley, J. P. (2016). Sedimentary records of mercury stable isotopes in Lake Michigan. Elementa: Science of the Anthropocene, 4, 000086. https://doi.org/10.12952/journal.elementa.000086

Yohn, S., Long, D., Fett, J., \& Patino, L. (2004). Regional versus local influences on lead and cadmium loading to the Great Lakes region. Applied Geochemistry, 19(7), 1157-1175. https://doi.org/10.1016/j.apgeochem.2004.01.013

Yuan, F. (2017). A multi-element sediment record of hydrological and environmental changes from Lake Erie since 1800. Journal of Paleolimnology, 58(1), 23-42. https://doi.org/10.1007/s10933-017-9953-3

Yuan, F., Depew, R., \& Soltis-Muth, C. (2014). Ecosystem regime change inferred from the distribution of trace metals in Lake Erie sediments. Scientific Reports, 4(1). https://doi.org/10.1038/srep07265 


\section{Table 1 (on next page)}

All known geochemical studies in the Laurentian Great Lakes, including the lengths of sedimentary profiles and metallic elements and oxides considered. 


\begin{tabular}{|c|c|c|c|}
\hline Reference & Location & $\begin{array}{l}\text { Max Core Length } \\
\text { (Time Period) }\end{array}$ & Analytes \\
\hline Nussmann (1965) & Lake Superior & $20 \mathrm{~cm}(1962)$ & $\begin{array}{l}\mathrm{Al}, \mathrm{As}, \mathrm{Ba}, \mathrm{Be}, \mathrm{Cd}, \mathrm{Co}, \mathrm{Cr} \\
\mathrm{Cu}, \mathrm{Fe}, \mathrm{Li}, \mathrm{Mn}, \mathrm{Mo}, \mathrm{Ni}, \mathrm{Pb} \\
\mathrm{Sb}, \mathrm{Sn}, \mathrm{Sr}, \mathrm{V}, \mathrm{Zn}\end{array}$ \\
\hline Callender (1969) & $\begin{array}{l}\text { Lake Michigan and } \\
\text { Superior }\end{array}$ & $80 \mathrm{~cm}(1968)$ & $\mathrm{Ca}, \mathrm{Fe}, \mathrm{Mg}, \mathrm{Mn}$ \\
\hline $\begin{array}{l}\text { Ruch, Kennedy \& } \\
\text { Shimp (1970) }\end{array}$ & $\begin{array}{l}\text { Southern Lake } \\
\text { Michigan }\end{array}$ & $325 \mathrm{~cm}(1969)$ & As \\
\hline $\begin{array}{l}\text { Schleicher \& Kuhn } \\
\text { (1970) }\end{array}$ & $\begin{array}{l}\text { Southern Lake } \\
\text { Michigan }\end{array}$ & $325 \mathrm{~cm}(1969)$ & $\mathrm{P}$ \\
\hline $\begin{array}{l}\text { Shimp, Leland, \& } \\
\text { White (1970) }\end{array}$ & $\begin{array}{l}\text { Southern Lake } \\
\text { Michigan }\end{array}$ & $325 \mathrm{~cm}(1969)$ & $\begin{array}{l}\mathrm{Al}, \mathrm{Be}, \mathrm{Ca}, \mathrm{Cr}, \mathrm{Fe}, \mathrm{K}, \mathrm{Mg} \\
\mathrm{Mn}, \mathrm{Ni}, \mathrm{P}, \mathrm{Pb}, \mathrm{Si}, \mathrm{Ti}, \mathrm{V}\end{array}$ \\
\hline $\begin{array}{l}\text { Kennedy, Ruch \& } \\
\text { Shimp (1971) }\end{array}$ & $\begin{array}{l}\text { Southern Lake } \\
\text { Michigan }\end{array}$ & $325 \mathrm{~cm}(1969)$ & $\mathrm{Hg}$ \\
\hline Shimp et al. (1971) & $\begin{array}{l}\text { Southern Lake } \\
\text { Michigan }\end{array}$ & $325 \mathrm{~cm}(1969)$ & $\begin{array}{l}\mathrm{B}, \mathrm{Be}, \mathrm{Br}, \mathrm{Cr}, \mathrm{Co}, \mathrm{Cu}, \mathrm{La} \\
\mathrm{MnO}, \mathrm{Ni}, \mathrm{Pb}, \mathrm{Sc}, \mathrm{V}, \mathrm{Zn}\end{array}$ \\
\hline $\begin{array}{l}\text { Cronan \& Thomas } \\
\text { (1972) }\end{array}$ & Lake Ontario & $100 \mathrm{~cm}(1970)$ & $\mathrm{Al}, \mathrm{Ca}, \mathrm{Fe}, \mathrm{K}, \mathrm{Mn}, \mathrm{P}, \mathrm{S}, \mathrm{Ti}$ \\
\hline $\begin{array}{c}\text { Kemp, Gray \& } \\
\text { Mudrochova (1972) }\end{array}$ & $\begin{array}{l}\text { Lakes Ontario, Erie, } \\
\text { and Huron }\end{array}$ & $50 \mathrm{~cm}(1800-1970)$ & $\mathrm{C}, \mathrm{N}, \mathrm{P}, \mathrm{S}$ \\
\hline Kovacik (1972) & Western Lake Erie & $60 \mathrm{~cm}(1971)$ & $\mathrm{Hg}$ \\
\hline $\begin{array}{l}\text { Mothersill \& Fung } \\
\text { (1972) }\end{array}$ & $\begin{array}{l}\text { Northern Lake } \\
\text { Superior basin }\end{array}$ & $\begin{array}{c}738 \mathrm{~cm}(11,270 \mathrm{yr} \\
\mathrm{BP}-1971)\end{array}$ & $\mathrm{Ca}, \mathrm{Cr}, \mathrm{Cu}, \mathrm{Fe}, \mathrm{Mn}, \mathrm{Ni}, \mathrm{Sr}, \mathrm{Zn}$ \\
\hline Thomas (1972) & Lake Ontario & $50 \mathrm{~cm}(1968)$ & $\mathrm{Hg}$ \\
\hline Walters et al. (1972) & Western Lake Erie & $117 \mathrm{~cm}(1971)$ & $\mathrm{Hg}$ \\
\hline $\begin{array}{l}\text { Williams \& Mayer } \\
(1972)\end{array}$ & $\begin{array}{l}\text { Lakes Erie and } \\
\text { Ontario }\end{array}$ & $\begin{array}{c}15 \mathrm{~m}(10,000 \mathrm{yr} \mathrm{BP} \\
-1971)\end{array}$ & $\mathrm{P}$ \\
\hline $\begin{array}{l}\text { Leland, Shukla \& } \\
\text { Shimp (1973) }\end{array}$ & $\begin{array}{l}\text { Southern Lake } \\
\text { Michigan }\end{array}$ & $100 \mathrm{~cm}(1969)$ & $\mathrm{Br}, \mathrm{Cr}, \mathrm{Cu}, \mathrm{Pb}, \mathrm{Zn}$ \\
\hline $\begin{array}{l}\text { Edgington, Robbins \& } \\
\text { Karttunen (1974) }\end{array}$ & Lake Michigan & $20 \mathrm{~cm}(1830-1972)$ & $\mathrm{Pb}$ \\
\hline Kemp et al. (1974) & $\begin{array}{l}\text { Lakes Ontario, Erie, } \\
\text { and Huron }\end{array}$ & $\begin{array}{c}100 \mathrm{~cm}(\text { Pre- } 1800- \\
1970)\end{array}$ & $\mathrm{C}, \mathrm{Hg}, \mathrm{N}, \mathrm{P}$ \\
\hline $\begin{array}{l}\text { Robbins \& Edgington } \\
\text { (1974) }\end{array}$ & $\begin{array}{l}\text { Southern Lake } \\
\text { Michigan }\end{array}$ & $40 \mathrm{~cm}(1969)$ & $\mathrm{Pb}$ \\
\hline $\begin{array}{l}\text { Robbins, Edgington \& } \\
\text { Parker (1974) }\end{array}$ & Lake Michigan & $15 \mathrm{~cm}(1884-1974)$ & $\mathrm{SiO}_{2}$ \\
\hline $\begin{array}{l}\text { Sridharan \& Lee } \\
\qquad(1974)\end{array}$ & $\begin{array}{l}\text { Lower Green Bay, } \\
\text { Lake Michigan }\end{array}$ & $40 \mathrm{~cm}(1969)$ & $\mathrm{Al}, \mathrm{Ca}, \mathrm{Fe}, \mathrm{P}$ \\
\hline $\begin{array}{l}\text { Walters, Kovacik \& } \\
\text { Herdendorf (1974) }\end{array}$ & Western Lake Erie & $60 \mathrm{~cm}(1972)$ & $\mathrm{Hg}$ \\
\hline $\begin{array}{l}\text { Walters \& Wolery } \\
\text { (1974) }\end{array}$ & Lake Erie & $60 \mathrm{~cm}(1973)$ & $\mathrm{Cr}, \mathrm{Hg}, \mathrm{Ni}$ \\
\hline $\begin{array}{l}\text { Walters, Wolery \& } \\
\text { Myser (1974) }\end{array}$ & Lake Erie & $120 \mathrm{~cm}(1972)$ & $\begin{array}{l}\mathrm{As}, \mathrm{Cd}, \mathrm{Co}, \mathrm{Cr}, \mathrm{Cu}, \mathrm{Fe}, \mathrm{Hg} \\
\mathrm{Ni}, \mathrm{Sb}, \mathrm{Zn}\end{array}$ \\
\hline
\end{tabular}




\begin{tabular}{|c|c|c|c|}
\hline $\begin{array}{c}\text { Wolery and Walters } \\
\text { (1974) }\end{array}$ & Western Lake Erie & $50 \mathrm{~cm}(1972)$ & $\mathrm{Hg}$ \\
\hline $\begin{array}{l}\text { Fitchko \& Hutchinson } \\
\text { (1975) }\end{array}$ & $\begin{array}{l}\text { River mouths around } \\
\text { the Great Lakes }\end{array}$ & $60 \mathrm{~cm}(1973)$ & $\begin{array}{l}\mathrm{Ag}, \mathrm{Cd}, \mathrm{Co}, \mathrm{Cr}, \mathrm{Cu}, \mathrm{Hg}, \mathrm{Mn} \\
\mathrm{Ni}, \mathrm{Pb}, \mathrm{Zn}\end{array}$ \\
\hline Petersen (1975) & Lake Erie & $\begin{array}{c}500 \mathrm{~cm}(\sim 7,500 \mathrm{yr} \\
\text { BP }-1967)\end{array}$ & $\mathrm{Ca}, \mathrm{Mg}, \mathrm{P}$ \\
\hline $\begin{array}{l}\text { Robbins \& Callender } \\
\text { (1975) }\end{array}$ & Lake Michigan & $350 \mathrm{~cm}(1972)$ & $\mathrm{Mn}$ \\
\hline $\begin{array}{l}\text { Edgington \& Robbins } \\
\text { (1976) }\end{array}$ & $\begin{array}{l}\text { Southern Lake } \\
\text { Michigan }\end{array}$ & $18 \mathrm{~cm}(1972)$ & $\mathrm{Pb}$ \\
\hline Förstner (1976) & $\begin{array}{l}\text { Lakes Erie and } \\
\text { Michigan }\end{array}$ & Review Article & \\
\hline $\begin{array}{l}\text { Kemp \& Thomas } \\
\text { (1976a) }\end{array}$ & $\begin{array}{l}\text { Lakes Ontario, Erie, } \\
\text { and Huron }\end{array}$ & $140 \mathrm{~cm}(1970)$ & $\begin{array}{l}\mathrm{Al}, \mathrm{Be}, \mathrm{Ca}, \mathrm{Cd}, \mathrm{Cu}, \mathrm{Fe}, \mathrm{K} \\
\mathrm{Mg}, \mathrm{Mn}, \mathrm{Na}, \mathrm{P}, \mathrm{Pb}, \mathrm{S}, \mathrm{Si}, \mathrm{Ti} \\
\mathrm{V}, \mathrm{Zn}\end{array}$ \\
\hline $\begin{array}{l}\text { Kemp \& Thomas } \\
\text { (1976b) }\end{array}$ & $\begin{array}{l}\text { Lakes Ontario, Erie, } \\
\text { and Huron }\end{array}$ & $140 \mathrm{~cm}(1970)$ & $\begin{array}{l}\mathrm{Al}, \mathrm{Be}, \mathrm{Ca}, \mathrm{Cd}, \mathrm{Cu}, \mathrm{Fe}, \mathrm{K} \\
\mathrm{Mg}, \mathrm{Mn}, \mathrm{Na}, \mathrm{P}, \mathrm{Pb}, \mathrm{S}, \mathrm{Si}, \mathrm{Ti} \\
\mathrm{V}, \mathrm{Zn}\end{array}$ \\
\hline Kemp et al. (1976) & Lake Erie & $140 \mathrm{~cm}(1970)$ & $\begin{array}{l}\mathrm{Al}, \mathrm{Be}, \mathrm{Ca}, \mathrm{Cd}, \mathrm{Cu}, \mathrm{Fe}, \mathrm{K} \\
\mathrm{Mg}, \mathrm{Mn}, \mathrm{Na}, \mathrm{P}, \mathrm{Pb}, \mathrm{S}, \mathrm{Si}, \mathrm{Ti} \\
\mathrm{V}, \mathrm{Zn}\end{array}$ \\
\hline $\begin{array}{l}\text { Robbins \& Edgington } \\
\qquad(1976)\end{array}$ & $\begin{array}{l}\text { Southern Lake } \\
\text { Michigan }\end{array}$ & $24 \mathrm{~cm}(1800-1972)$ & $\begin{array}{l}\text { As, } \mathrm{Ba}, \mathrm{Br}, \mathrm{Ca}, \mathrm{Ce}, \mathrm{Co}, \mathrm{Cr}, \\
\mathrm{Cs}, \mathrm{Cu}, \mathrm{Eu}, \mathrm{Fe}, \mathrm{Gf}, \mathrm{K}, \mathrm{La}, \mathrm{Lu} \text {, } \\
\mathrm{Mg}, \mathrm{Mn}, \mathrm{Na}, \mathrm{Ni}, \mathrm{Pb}, \mathrm{Rb}, \mathrm{Sb}, \\
\mathrm{Se}, \mathrm{Sm}, \mathrm{Tb}, \mathrm{Th}, \mathrm{U}, \mathrm{Zn}\end{array}$ \\
\hline Torrey (1976) & Lake Michigan & Review Article & \\
\hline $\begin{array}{l}\text { Williams, Murphy \& } \\
\text { Mayer (1976) }\end{array}$ & Lake Erie & $20 \mathrm{~cm}(1971)$ & $\mathrm{P}$ \\
\hline Mothersill (1977) & $\begin{array}{l}\text { Thunder Bay, Lake } \\
\text { Superior }\end{array}$ & 35 cm (1974) & $\mathrm{Co}, \mathrm{Cr}, \mathrm{Cu}, \mathrm{Fe}, \mathrm{Mn}, \mathrm{Ni}, \mathrm{Zn}$ \\
\hline Nriagu (1978) & $\begin{array}{l}\text { Lakes Ontario, } \\
\text { Superior, and Erie }\end{array}$ & $30 \mathrm{~cm}(1975)$ & $\mathrm{SiO}_{2}$ \\
\hline Kemp et al. (1978) & $\begin{array}{l}\text { Lakes Superior and } \\
\text { Huron }\end{array}$ & $75 \mathrm{~cm}(1970)$ & $\begin{array}{l}\mathrm{Al}, \mathrm{Be}, \mathrm{Ca}, \mathrm{Cd}, \mathrm{Cu}, \mathrm{Fe}, \mathrm{K} \\
\mathrm{Mg}, \mathrm{Mn}, \mathrm{Na}, \mathrm{P}, \mathrm{Pb}, \mathrm{S}, \mathrm{Si}, \mathrm{Ti} \\
\text { V, Zn }\end{array}$ \\
\hline Warwick (1978) & $\begin{array}{c}\text { Bay of Quinte, Lake } \\
\text { Ontario }\end{array}$ & $\begin{array}{l}2 \mathrm{~m}(874 \text { B.C. }- \\
1972)\end{array}$ & $\mathrm{P}$ \\
\hline Nriagu et al. (1979) & Lake Erie & $30 \mathrm{~cm}(1976)$ & $\mathrm{Cd}, \mathrm{Cu}, \mathrm{Pb}, \mathrm{Zn}$ \\
\hline Robbins (1980) & Southern Lake Huron & $50 \mathrm{~cm}(1975)$ & $\begin{array}{l}\mathrm{Al}, \mathrm{As}, \mathrm{Ba}, \mathrm{Br}, \mathrm{Ca}, \mathrm{Cd}, \mathrm{Ce}, \\
\mathrm{Co}, \mathrm{Cr}, \mathrm{Cs}, \mathrm{Cu}, \mathrm{Eu}, \mathrm{Fe}, \mathrm{K}, \mathrm{La}, \\
\mathrm{Lu}, \mathrm{Hg}, \mathrm{Hf}, \mathrm{Mg}, \mathrm{Mo}, \mathrm{Mn}, \mathrm{Na}, \\
\mathrm{Ni}, \mathrm{P}, \mathrm{Pb}, \mathrm{Rb}, \mathrm{Sb}, \mathrm{Sc}, \mathrm{Si}, \mathrm{Sm}, \\
\mathrm{Sn}, \mathrm{Sr}, \mathrm{Ti}, \mathrm{Th}, \mathrm{U}, \mathrm{V}, \mathrm{Yb}, \mathrm{Zn}\end{array}$ \\
\hline $\begin{array}{l}\text { Christensen \& Chien } \\
\text { (1981) }\end{array}$ & $\begin{array}{l}\text { Green Bay and } \\
\text { Northern Lake } \\
\text { Michigan }\end{array}$ & $15 \mathrm{~cm}(1751-1978)$ & $\mathrm{As}, \mathrm{Cd}, \mathrm{Pb}, \mathrm{Zn}$ \\
\hline
\end{tabular}




\begin{tabular}{|c|c|c|c|}
\hline Goldberg et al. (1981) & Lake Michigan & $60 \mathrm{~cm}(1830-1978)$ & $\begin{array}{l}\mathrm{Al}, \mathrm{Cd}, \mathrm{Co}, \mathrm{Cr}, \mathrm{Cu}, \mathrm{Fe}, \mathrm{Mn}, \\
\mathrm{Ni}, \mathrm{Pb}, \mathrm{Sn}, \mathrm{V}, \mathrm{Zn}\end{array}$ \\
\hline $\begin{array}{l}\text { Manning, Lum \& } \\
\text { Birchall (1983) }\end{array}$ & Lake Ontario & $15 \mathrm{~cm}(1820-1981)$ & $\begin{array}{l}\mathrm{Al}, \mathrm{Ca}, \mathrm{Cd}, \mathrm{Co}, \mathrm{Cr}, \mathrm{Cu}, \mathrm{Fe} \\
\mathrm{Mn}, \mathrm{Ni}, \mathrm{P}, \mathrm{Pb}, \mathrm{Zn}\end{array}$ \\
\hline $\begin{array}{l}\text { Nriagu, Wong \& } \\
\text { Snodgrass (1983) }\end{array}$ & $\begin{array}{c}\text { Toronto and } \\
\text { Hamilton Harbors }\end{array}$ & $100 \mathrm{~cm}(1981)$ & $\begin{array}{l}\mathrm{Cd}, \mathrm{Cr}, \mathrm{Cu}, \mathrm{Fe}, \mathrm{Mn}, \mathrm{Ni}, \mathrm{Pb}, \\
\mathrm{Zn}\end{array}$ \\
\hline Breteler et al. (1984) & $\begin{array}{l}\text { Lake Ontario, Lake } \\
\text { Erie, Niagara River }\end{array}$ & $66 \mathrm{~cm}(1934-1979)$ & $\mathrm{Hg}$ \\
\hline $\begin{array}{l}\text { Schelske, Conley \& } \\
\text { Warwick (1985) }\end{array}$ & $\begin{array}{c}\text { Bay of Quinte (Lake } \\
\text { Ontario) }\end{array}$ & $\begin{array}{c}164 \mathrm{~cm}(874 \mathrm{BC}- \\
1972)\end{array}$ & $\mathrm{P}$ \\
\hline Schelske et al. (1988) & $\begin{array}{l}\text { Rochester Basin } \\
\text { (Lake Ontario) }\end{array}$ & $150 \mathrm{~cm}(1981)$ & $\mathrm{P}$ \\
\hline $\begin{array}{l}\text { Christensen \& Osuna } \\
\text { (1989) }\end{array}$ & Lake Michigan & $84.0 \mathrm{~cm}(1984)$ & $\mathrm{Cd}, \mathrm{Pb}, \mathrm{Zn}$ \\
\hline McKee et al. (1989) & $\begin{array}{l}\text { Caribou sub-basin of } \\
\text { Lake Superior }\end{array}$ & $32 \mathrm{~cm}(1986)$ & $\mathrm{Cu}, \mathrm{Mn}, \mathrm{Pb}$ \\
\hline Schelske (1991) & $\begin{array}{l}\text { Rochester Basin } \\
\text { (Lake Ontario) }\end{array}$ & $150 \mathrm{~cm}(1981)$ & $\mathrm{P}$ \\
\hline Sly (1991) & Lake Ontario & $25 \mathrm{~cm}(1750-1972)$ & $\mathrm{P}$ \\
\hline Mudroch (1993) & Lake Ontario & $15 \mathrm{~cm}(1989)$ & $\begin{array}{l}\mathrm{Al}, \mathrm{As}, \mathrm{Ca}, \mathrm{Co}, \mathrm{Cr}, \mathrm{Cu}, \mathrm{Fe}, \mathrm{K}, \\
\mathrm{Mg}, \mathrm{Mn}, \mathrm{Na}, \mathrm{Ni}, \mathrm{P}, \mathrm{Pb}, \mathrm{Si}, \mathrm{Ti}, \\
\mathrm{Zn}\end{array}$ \\
\hline $\begin{array}{l}\text { Kerfoot, Lauster \& } \\
\text { Robbins (1994) }\end{array}$ & Lake Superior & $40 \mathrm{~cm}(1850-1991)$ & $\mathrm{Cu}$ \\
\hline $\begin{array}{l}\text { Mayer and Johnson } \\
\text { (1994) }\end{array}$ & Hamilton Harbor & $60 \mathrm{~cm}(1898-1987)$ & $\mathrm{Cd}, \mathrm{Cu}, \mathrm{Fe}, \mathrm{Mn}, \mathrm{Ni}, \mathrm{P}, \mathrm{Pb}, \mathrm{Zn}$ \\
\hline Ritson et al. (1994) & Lake Erie & $60 \mathrm{~cm}(1926-1985)$ & $\mathrm{Pb}$ \\
\hline Graney et al. (1995) & Great Lakes basin & $\begin{array}{c}170 \mathrm{~cm}(1798- \\
1992)\end{array}$ & $\mathrm{Pb}$ \\
\hline Rossmann (1995) & Saginaw Bay & $65 \mathrm{~cm}(1820-1988)$ & $\mathrm{Cd}, \mathrm{Cr}, \mathrm{Cu}, \mathrm{Hg}, \mathrm{Ni}, \mathrm{Pb}, \mathrm{Zn}$ \\
\hline $\begin{array}{l}\text { Azcue, Rosa \& } \\
\text { Mudroch (1996) }\end{array}$ & Lake Erie & $46 \mathrm{~cm}(1819-1994)$ & $\begin{array}{l}\mathrm{Al}, \mathrm{As}, \mathrm{Ca}, \mathrm{Cd}, \mathrm{Cr}, \mathrm{Cu}, \mathrm{Fe}, \mathrm{K}, \\
\mathrm{Mg}, \mathrm{Mn}, \mathrm{Na}, \mathrm{Ni}, \mathrm{Pb}, \mathrm{Si}, \mathrm{Sr}, \\
\mathrm{Ti}, \mathrm{Zn}\end{array}$ \\
\hline Kolak et al. (1998) & $\begin{array}{l}\text { Lakes Michigan, } \\
\text { Ontario, and Superior }\end{array}$ & $70 \mathrm{~cm}(1800-1992)$ & $\mathrm{Cu}$ \\
\hline Pirrone et al. (1998) & $\begin{array}{l}\text { Lakes Ontario, } \\
\text { Michigan, Erie }\end{array}$ & $70 \mathrm{~cm}(1800-1988)$ & $\mathrm{Hg}$ \\
\hline Kerfoot et al. (1999) & Lake Superior & $50 \mathrm{~cm}(1983)$ & $\mathrm{Ag}, \mathrm{Cu}, \mathrm{Hg}, \mathrm{Zn}$ \\
\hline $\begin{array}{l}\text { Kerfoot \& Robbins } \\
\text { (1999) }\end{array}$ & Keweenaw Waterway & $60 \mathrm{~cm}(1991)$ & $\begin{array}{l}\mathrm{Al}, \mathrm{As}, \mathrm{Ba}, \mathrm{Ca}, \mathrm{Ce}, \mathrm{Co}, \mathrm{Cr} \\
\mathrm{Cs}, \mathrm{Cu}, \mathrm{Fe}, \mathrm{K}, \mathrm{Mn}, \mathrm{Na}, \mathrm{Zn}\end{array}$ \\
\hline Kolak et al. (1999) & Lake Superior & $70 \mathrm{~cm}(1994)$ & $\mathrm{Cu}, \mathrm{Zn}$ \\
\hline Painter et al. (2001) & Lake Erie & $140 \mathrm{~cm}(1997)$ & $\begin{array}{l}\mathrm{Al}, \mathrm{As}, \mathrm{Cd}, \mathrm{Cr}, \mathrm{Cu}, \mathrm{Fe}, \mathrm{Hg} \\
\mathrm{Mn}, \mathrm{N}, \mathrm{Ni}, \mathrm{P}, \mathrm{Pb}, \mathrm{Zn}\end{array}$ \\
\hline $\begin{array}{l}\text { Jeong \& McDowell } \\
\text { (2003) }\end{array}$ & $\begin{array}{l}\text { Copper Harbor (Lake } \\
\text { Superior) }\end{array}$ & $20 \mathrm{~cm}(2000)$ & $\mathrm{Cu}$ \\
\hline
\end{tabular}




\begin{tabular}{|c|c|c|c|}
\hline Marvin et al. (2003) & Lake Ontario & $60 \mathrm{~cm}(1998)$ & $\begin{array}{l}\mathrm{Al}, \mathrm{As}, \mathrm{Cd}, \mathrm{Cr}, \mathrm{Cu}, \mathrm{Fe}, \mathrm{Hg} \\
\mathrm{Mn}, \mathrm{N}, \mathrm{Ni}, \mathrm{P}, \mathrm{Pb}, \mathrm{Zn}\end{array}$ \\
\hline Rolfhus et al. (2003) & Lake Superior & $10 \mathrm{~cm}(2000$ & $\mathrm{Hg}$ \\
\hline Belzile et al. (2004) & $\begin{array}{l}\text { Killarney Park, } \\
\text { Ontario }\end{array}$ & $35 \mathrm{~cm}(2004)$ & $\begin{array}{l}\text { As. } \mathrm{Cd}, \mathrm{Cu}, \mathrm{Co} . \mathrm{Fe}, \mathrm{Mn}, \mathrm{Ni} \\
\mathrm{Pb}, \mathrm{Zn}\end{array}$ \\
\hline Kerfoot et al. (2004) & Lake Superior & $60 \mathrm{~cm}(1983)$ & $\mathrm{Ag}, \mathrm{Au}, \mathrm{Cu}, \mathrm{Hg}, \mathrm{Zn}$ \\
\hline Marvin et al. (2004) & Great Lakes & $60 \mathrm{~cm}(1840-2000)$ & $\mathrm{Hg}$ \\
\hline Reavie et al. (2005) & $\begin{array}{c}\text { Lake George } \\
\text { (Ontario, Canada) }\end{array}$ & $50 \mathrm{~cm}(1770-1993)$ & $\begin{array}{l}\text { Al, As, Br, Ca, Ce, Co, Cr, } \\
\text { Cs, Eu, Fe, Hf, La, Lu, Mn, } \\
\text { Na, Rb, Sb, Sc, Sm, Ta, Th, } \\
\text { Ti, V, Yb, Zn }\end{array}$ \\
\hline $\begin{array}{l}\text { Schelske, Stoermer \& } \\
\text { Kenney (2006) }\end{array}$ & Great Lakes & $80 \mathrm{~cm}(1800-1993)$ & $\mathrm{P}$ \\
\hline Rossmann (2010) & Lake Michigan & $69 \mathrm{~cm}(1884-1996)$ & $\mathrm{Hg}$ \\
\hline Drevnick et al. (2012) & Great Lakes & Review Article & $\mathrm{Hg}$ \\
\hline Pompeani et al. (2013) & Keweenaw Peninsula & $\begin{array}{c}360 \mathrm{~cm}(\sim 8800 \mathrm{yr} \\
\mathrm{BP}-2012)\end{array}$ & $\mathrm{Fe}, \mathrm{Mg}, \mathrm{Pb}, \mathrm{Ti}$ \\
\hline $\begin{array}{l}\text { Rossmann, Pfeiffer \& } \\
\text { Filkins (2014) }\end{array}$ & Lake Michigan & $69 \mathrm{~cm}(1884-1996)$ & $\mathrm{Pb}$ \\
\hline $\begin{array}{l}\text { Shaw Chraïbi et al. } \\
\text { (2014) }\end{array}$ & Lake Superior & $36 \mathrm{~cm}(1750-2010)$ & $\begin{array}{l}\mathrm{Al}, \mathrm{Ba}, \mathrm{Ca}, \mathrm{Fe}, \mathrm{K}, \mathrm{Mg}, \mathrm{Mn}, \\
\mathrm{Na}, \mathrm{P}, \mathrm{Si}, \mathrm{Sr}\end{array}$ \\
\hline $\begin{array}{l}\text { Yuan, Depew \& } \\
\text { Soltis-Muth (2014) }\end{array}$ & Lake Erie & $40 \mathrm{~cm}(1800-2012)$ & $\begin{array}{l}\mathrm{Al}, \mathrm{As}, \mathrm{Ba}, \mathrm{Be}, \mathrm{Ca}, \mathrm{Cd}, \mathrm{Co}, \\
\mathrm{Cr}, \mathrm{Cu}, \mathrm{Fe}, \mathrm{K}, \mathrm{Mg}, \mathrm{Mn}, \mathrm{Mo}, \\
\mathrm{Na}, \mathrm{Ni}, \mathrm{Pb}, \mathrm{Se}, \mathrm{Sn}, \mathrm{Ti}, \mathrm{V}, \mathrm{Zn}\end{array}$ \\
\hline Dittrich et al. (2015) & Lake Superior & $35 \mathrm{~cm}(2012)$ & $\mathrm{Fe}, \mathrm{Mn}$ \\
\hline Pompeani et al. (2015) & $\begin{array}{l}\text { McCargoe Cove, } \\
\text { Lake Superior }\end{array}$ & $\begin{array}{c}360 \mathrm{~cm}(\sim 8800 \mathrm{yr} \\
\mathrm{BP}-2012)\end{array}$ & $\mathrm{Cu}, \mathrm{Fe}, \mathrm{K}, \mathrm{Mg}, \mathrm{Pb}, \mathrm{Ti}$ \\
\hline Kerfoot et al. (2016) & Keweenaw Peninsula & $80 \mathrm{~cm}(1800-2004)$ & $\mathrm{Cu}, \mathrm{Hg}$ \\
\hline Yin et al. (2016) & Lake Michigan & $1720-2013$ & $\mathrm{Hg}$ \\
\hline Alsaffar (2017) & Lake St. Clair & $142 \mathrm{~cm}(2015)$ & $\begin{array}{l}\mathrm{As}, \mathrm{Ba}, \mathrm{Cd}, \mathrm{Cr}, \mathrm{Cu}, \mathrm{Fe}, \mathrm{Hg} \\
\mathrm{Mn}, \mathrm{Ni}, \mathrm{Pb}, \mathrm{Zn}\end{array}$ \\
\hline Sgro \& Reavie (2017) & Lake Erie & $49 \mathrm{~cm}(1870-2011)$ & $\begin{array}{l}\mathrm{Al}, \mathrm{Ca}, \mathrm{CaO}, \mathrm{Cd}, \mathrm{Cu}, \mathrm{Fe}, \mathrm{K}, \\
\mathrm{Mg}, \mathrm{MgO}, \mathrm{Na}, \mathrm{Ni}, \mathrm{Pb}, \mathrm{Si} \\
\mathrm{SiO}_{2}\end{array}$ \\
\hline Yuan (2017) & $\begin{array}{l}\text { Sandusky Basin, } \\
\text { Lake Erie }\end{array}$ & $40 \mathrm{~cm}(1800-2012)$ & $\begin{array}{l}\mathrm{Al}, \mathrm{Ca}, \mathrm{Fe}, \mathrm{K}, \mathrm{Mg}, \\
\mathrm{Mn}, \mathrm{Na}, \mathrm{As}, \mathrm{Ba}, \mathrm{Be}, \mathrm{Cd}, \mathrm{Co}, \\
\mathrm{Cr}, \mathrm{Cu}, \mathrm{Mo}, \mathrm{Ni}, \mathrm{Pb}, \mathrm{Se}, \mathrm{Sn} \\
\mathrm{Ti}, \mathrm{V}, \mathrm{Zn}\end{array}$ \\
\hline Sgro \& Reavie (2018) & Lake Huron & $36 \mathrm{~cm}(1823-2012)$ & $\begin{array}{l}\mathrm{Al}, \mathrm{Al}_{2} \mathrm{O}_{3}, \mathrm{As}, \mathrm{Ba}, \mathrm{BaO}, \mathrm{Ca}, \\
\mathrm{CaO}, \mathrm{Cd}, \mathrm{Co}, \mathrm{Cr}, \mathrm{Cs}, \mathrm{Cu}, \mathrm{Dy}, \\
\mathrm{Er}, \mathrm{Eu}, \mathrm{Fe}, \mathrm{Fe}_{2} \mathrm{O}_{3}, \mathrm{Ga}, \mathrm{Gd}, \\
\mathrm{Ho}, \mathrm{K}, \mathrm{K}_{2} \mathrm{O}, \mathrm{La}, \mathrm{Li}, \mathrm{Lu}, \mathrm{Mg}, \\
\mathrm{MgO}, \mathrm{Mn}, \mathrm{MnO}, \mathrm{Mo}, \mathrm{Na}, \\
\mathrm{Na}_{2} \mathrm{O}, \mathrm{Nb}, \mathrm{Nd}, \mathrm{Ni}, \mathrm{P}, \mathrm{P}_{2} \mathrm{O}_{5}, \\
\mathrm{~Pb}, \mathrm{Pr}, \mathrm{Rb}, \mathrm{Sb}, \mathrm{Sc}, \mathrm{Si}, \mathrm{SiO}_{2}, \\
\mathrm{Sm}, \mathrm{Sn}, \mathrm{SrO}, \mathrm{Ta}, \mathrm{Tb}, \mathrm{Th},\end{array}$ \\
\hline
\end{tabular}




\section{Table 2 (on next page)}

Range of As concentrations in ppm in different rock types.

Modified and combined version of two tables presented and included in a study by the National Research Council (1977). 
Arsenic Concentration, ppm

\begin{tabular}{|llll|}
\hline Igneous Rocks & No. Analyses & Range Usually Reported & Average \\
\hline Ultrabasic & 37 & $0.3-16$ & 3.0 \\
Basalts, gabbros & 146 & $0.06-113$ & 2.0 \\
Andesites, dacites & 41 & $0.5-5.8$ & 2.0 \\
Granitic & 73 & $0.2-13.8$ & 1.5 \\
Silicic volcanic & 52 & $0.2-12.2$ & 3.0 \\
\hline & & & Average \\
\hline Sedimentary Rocks & No. Analyses & Range Usually Reported & 1.7 \\
\hline Limestones & 37 & $0.1-20$ & 2.0 \\
Sandstones & 11 & $0.6-120$ & $14.5^{\mathrm{a}}$ \\
Shales and clays & 324 & $0.3-490$ & 22.6 \\
Phosphorites & 282 & $0.4-188$ & $400 ?$ \\
Sedimentary iron ores & 110 & $1-2,900$ & $($ up to $1.5 \%)$ \\
Sedimentary manganese ores & - & $0-2,000$ & $13^{\mathrm{b}}$ \\
Coal & 1,150 & & \\
\hline
\end{tabular}

1

2 Estimated on the basis of data of Onishi (1969) and Boyle and Jonasson (1973).

3 aExcluding one sample with arsenic at $490 \mathrm{ppm}$

$4 \quad{ }^{b}$ Boyle and Jonasson (1973) gave 4 ppm 


\section{Figure 1}

Geological map of the Great Lakes watershed.

Geology of the region is summarized by geological age which is matched to rock types in the description. The basin is bounded to the north by the upland Precambrian-age Canadian Shield. The basin is bound to the south by a lowland region of Paleozoic sedimentary rocks. The Midcontinent Rift System makes up the western Lake Superior basin. United States data are from the USGS (USGS, 2018) and state geological surveys. Canadian data are taken from GeologyOntario (Ontario Ministry of Energy, Northern Development and Mines, 2019).

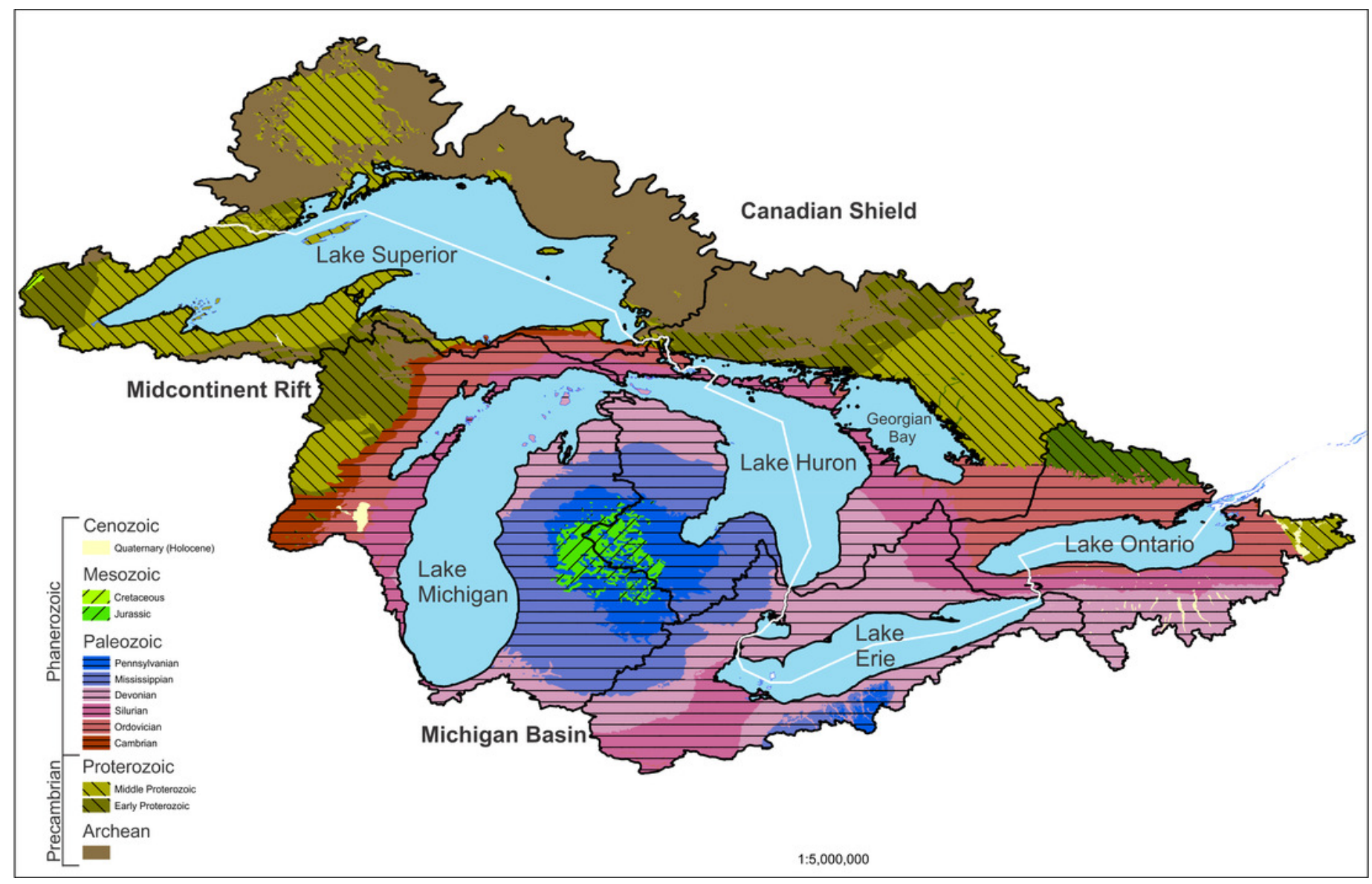

